\title{
Cashew Nut Allergy: Clinical Relevance and Allergen Characterisation
}

\author{
Cíntia Mendes ${ }^{1} \cdot$ Joana Costa $^{1}$ (i) - António A. Vicente ${ }^{2} \cdot$ Maria Beatriz P. P. Oliveira $^{1} \cdot$ \\ Isabel Mafra ${ }^{1}$
}

Published online: 1 September 2016

(C) Springer Science+Business Media New York 2016

\begin{abstract}
Cashew plant (Anacardium occidentale L.) is the most relevant species of the Anacardium genus. It presents high economic value since it is widely used in human nutrition and in several industrial applications. Cashew nut is a wellappreciated food (belongs to the tree nut group), being widely consumed as snacks and in processed foods by the majority of world's population. However, cashew nut is also classified as a potent allergenic food known to be responsible for triggering severe and systemic immune reactions (e.g. anaphylaxis) in sensitised/allergic individuals that often demand epinephrine treatment and hospitalisation. So far, three groups of allergenic proteins have been identified and characterised in cashew nut: Ana o 1 and Ana o 2 (cupin superfamily) and Ana o 3 (prolamin superfamily), which are all classified as major allergens. The prevalence of cashew nut allergy seems to be rising in industrialised countries with the increasing consumption of this nut. There is still no cure for cashew nut allergy, as well as for other food allergies; thus, the allergic patients are advised to eliminate it from their diets. Accordingly, when carefully choosing processed foods that are commercially available, the allergic consumers have to rely on proper food labelling. In this sense, the control of labelling compliance is much needed, which has prompted the development of proficient analytical
\end{abstract}

Cíntia Mendes and Joana Costa contributed equally to this work.

Joana Costa

jbcosta@ff.up.pt

Isabel Mafra

isabel.mafra@ff.up.pt

1 REQUIMTE-LAQV, Faculdade de Farmácia, Universidade do Porto, Rua de Jorge Viterbo Ferreira, 228, 4050-313 Porto, Portugal

2 CEB, Centro de Engenharia Biológica, Universidade do Minho, Campus de Gualtar, 4710-057 Braga, Portugal methods for allergen analysis. In the recent years, significant research advances in cashew nut allergy have been accomplished, which are highlighted and discussed in this review.

Keywords Anacardium occidentale L. · Food allergy ·

Allergens · Prevalence · Threshold levels · Immunotherapy · Clinical relevance $\cdot$ Cashew detection

\section{Introduction}

Cashew plant (Anacardium occidentale L.) belongs to the Anacardiaceae family, which comprises nine species of the Anacardium genus [1]. A. occidentale is the most relevant in terms of economic interest, although other trees and shrubs of this genus have begun to gain special attention. Additional data on each species is presented in Table 1, namely their geographical distribution, applications and potential allergenic proteins.

A. occidentale is a tropical evergreen tree that is well known for its fruits and seeds. The cashew fruit (cashew apple) is actually a swollen peduncle (pseudofruit) with sweet flavour and aroma. The pulpy and juicy part of cashew apple is highly popular, being consumed as juices, jams and alcoholic beverages $[2,3]$. The cashew nut (seed) grows externally, inside a hard shell, at the end of the peduncle. The hard shell is composed by two layers that form a honeycomb structure containing an oily substance (phenolic cashew nut shell liquid), which presents several industrial applications, namely in plastic, paint, resin and surface coating industries [2]. Inside the hard shell and protected from the oily substance lays the kernel (cashew nut) that is a rich source of protein, carbohydrate and triglyceride oil. Cashew nuts are normally consumed roasted and salted, being worldwide appreciated as snacks. 


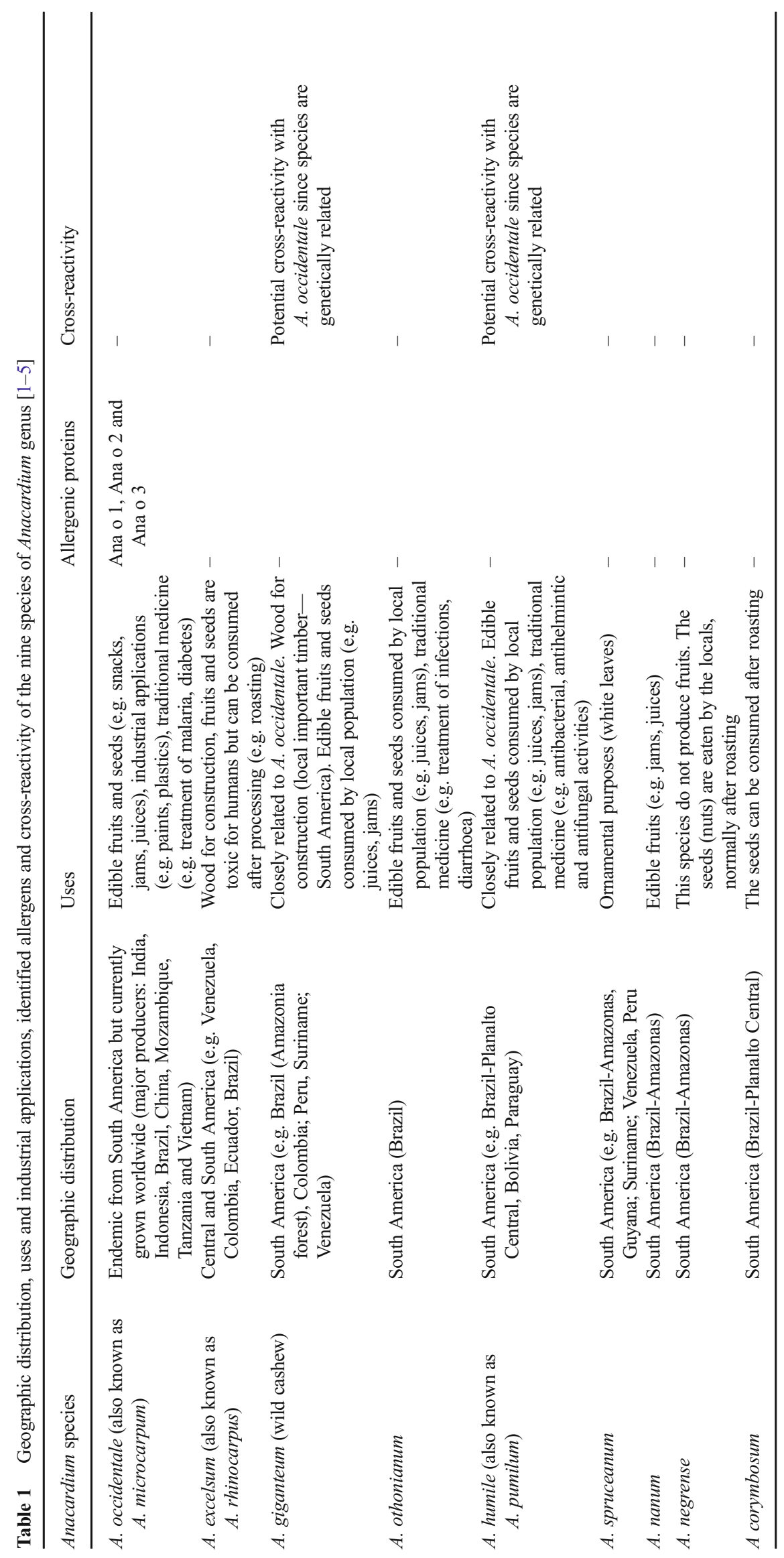


A. occidentale species originated from South America (e.g. Brazil, Venezuela), but it is currently cultivated in several countries of Africa and Asia (e.g. Vietnam, India, United Republic of Tanzania, Indonesia) [6]. In 2013, Vietnam was the main producer of cashew nut with shell, thus assuring $25 \%$ of its global production. In the same year and in terms of trade, cashew nut ranked second place just behind almond [6]. Included in the tree nuts, cashew nut is also related to several beneficial health effects that are commonly attributed to this group of nuts. Accordingly, cashew nut and its coproducts have a long history of worldwide application in traditional medicine for the treatment of different health conditions, such as asthma, diabetes, skin infections and inflammation, amongst others (Table 1) [3]. However, no clinical studies have yet proven its actual medicinal efficacy [7].

Owing to the health food claims attributed by the World Health Organization and the Food and Agriculture Organization (WHO/FAO) to tree nuts [8], the consumption of cashew nut and other tree nuts has been increasing in the past years. However, cashew (nut and fruit) can also represent a concrete health risk for a small but rather significant part of the world's population, namely the food-sensitised/allergic individuals.

With the increasing awareness that food allergies represent an important public health problem, legal measures have been established to protect the life of those individuals. In 1985, the Codex Alimentarius Commission issued a recommendation for mandatory labelling of pre-packaged foods susceptible of containing potentially allergenic ingredients. Accordingly, a list of priority allergenic foods (tree nuts, peanuts, glutencontaining cereals, soybean, fish, eggs, milk and crustaceans) and sulphites was proposed by the Codex Alimentarius Commission [9]. Within the European Union (EU), the first priority list was issued by the Directive 2003/89/EC [10], adding sesame, celery and mustard to the previous list [9], totalising 12 groups of allergenic foods. Since then, the EU has established legislation increasing the priority list of allergens to 14 groups (by adding molluscs and lupine) that are required to be emphasised from the rest of the ingredients enumerated in processed foods, regardless of their quantity $[11,12]$. Using the Codex Alimentarius Commission and/or the EU standards as guidelines, many countries have adopted allergen labelling regulatory frameworks [13, 14]. Owing to the fact that tree nuts are one of the eight groups responsible for a great number of allergic reactions, they are included in the list of allergenic foods with mandatory labelling in most countries/regions (e.g. USA, Canada, EU), with exception of Japan and Korea $[13,14]$.

In the recent years, significant research advances in cashew nut allergy, namely prevalence, diagnosis, immunotherapy, clinical relevance and thresholds, as well as biochemical characterisation of cashew nut allergens, processing and digestibility studies, management and method development for its detection, have been achieved. The research progresses in cashew nut allergy have been summarised and discussed in this review.

\section{Epidemiology of Cashew Allergy}

The definition of the prevalence of food allergies has been estimated on the basis of different indicators. Amongst them, surveys and questionnaires have been widely used to predict the prevalence of several food allergies. However, the retrieved information must be carefully evaluated since the sensitised/allergic individuals might overrate self-allergic symptoms. To overcome these drawbacks, more objective indicators, such as provocation food tests (open food challenges (OFC) and double-blind placebo-controlled food challenges (DBPCFC)) or in vitro (serum $\mathrm{IgE}$ ) and in vivo (skin prick tests (SPT)) diagnostic tools, to assess food sensitisation are recommended [15]. However, OFC and DBPCFC studies are more difficult to perform since their assessment is highly dependent on the collaboration of the allergic individuals.

So far, there are several studies reporting prevalence data about tree nut allergies, but only a few specify information regarding individual nuts (e.g. cashew nut). Additionally, most of the reports involve small geographical regions (e.g. city, country), which retrains a broad overview about the real prevalence of cashew nut or other food allergies. Literature reporting the prevalence of cashew nut allergy is available for some countries in Europe, the USA and Australia, but no information could be retrieved from emergent economies (Asia or Africa).

Like other nuts, the prevalence of cashew nut allergy varies from region to region, presenting its highest reported incidence in the USA [16]. A voluntary registration involving 5149 participants with peanut and tree nut allergies from 48 states was established in 1997 to evaluate their prevalence in the USA. On the basis of a structured questionnaire that encompassed peanut and different nuts, it was possible to estimate that walnut (34\%) and cashew nut (20\%) allergies presented the highest incidence rate amongst allergic patients [17]. Using more objective indicators, such as SPT and DBPCFC, Fleischer et al. [18] reported high prevalence of walnut and cashew nut allergies, both with $30 \%$ in a USA test population of 101 patients with previous clinical diagnosis of tree nut allergies.

Besides USA, cashew nut allergy also seems to be epidemiologically increasing in other regions over the past years, namely in Northern Europe [19, 20]. A study using clinical records from a hospital in Uppsala County (Sweden) over a 10-year period (2001-2010) evidenced that peanuts and tree nuts accounted for $50 \%$ of the 703 food allergic cases in children $(<18$ years), being more frequently associated with epinephrine treatment and hospitalisation. Over the same 
period, the estimated prevalence of cashew nut allergy was $6 \%$ of food allergic individuals, with reports of increasing frequency and severity of episodes caused by cashew nut ingestion [19]. In a different region of Sweden (Stockholm County), similar data could be retrieved from three paediatric hospitals in 2007. Accordingly, $15 \%$ of the reported food allergies in children were attributed to tree nuts. From those, $5 \%$ were triggered by cashew nut ingestion with most patients experiencing anaphylaxis [20]. In a 3-year follow-up study involving 139 tree nut allergic adults from Utrecht (Netherlands), cashew nut allergy was estimated with a prevalence of $20 \%$ [21]. In France, Moneret-Vautrin [22] estimated an incidence of $10.3 \%$ of cashew nut allergy on a test population of 141 patients, reporting that the number of anaphylaxis cases increased from 3 to $9 \%$ between 2003 and 2007, respectively.

In a 5-year study (1999-2003) based on clinical records from a paediatric hospital in Australia (Melbourne), peanut (18\%) and cashew nut (13\%) were the most common cause for anaphylaxis in children [23]. Similar prevalence of cashew nut allergy (12.6\%) was described by Davoren and Peake [24] using clinical reports of a test population comprising 213 peanut and tree nut allergic children $(<18$ years $)$ from Brisbane (Australia) during a period of 42 months. Moreover, in patients with diagnosed cashew nut allergy, more than $74 \%$ had experienced severe and life-threatening episodes, such as anaphylaxis [24].

\section{Diagnosis, Therapy and Immunotherapy}

Cashew nut allergy is a classical IgE-mediated disorder. The ingestion of cashew nut seems to be the principal sensitisation path for its allergy, although mechanisms associated with poor skin barrier function (atopic dermatitis) and loss of function in the filaggrin gene have been also highlighted as increasing risk factors for the development of cashew nut and other food allergies $[25,26]$. Like for most of food allergies, the initial diagnosis of cashew nut allergy is usually built on the basis of a clear definition of a medical history [27, 28]. Accordingly, several aspects, such as the amount of ingested cashew nut, the type of clinical presentations and organs/systems (skin, gastrointestinal or respiratory) affected, the temporal association between ingestion and the appearance of the first observable symptoms and the symptoms after eating similar foods, must be considered [27].

Following a record of medical history, diagnostic testing methods, namely the use of in vivo SPT and/or in vitro fluorescent-enzyme immunoassays (FEIA-CAP) or radioallergosorbent tests (RAST), are recommended. The SPT are performed by placing a small amount of the allergen into the skin, eliciting a localised allergic reaction in the form of a wheal at the testing site, whilst the FEIA-CAP and RAST are based on the detection of specific IgE in serum. However, these tests can only be considered as mere indicators of sensitisation rather than truly predictive tools for food allergy. In spite of presenting high sensitivities, negative results of the diagnostic in vivo and/or in vitro tests cannot be considered for allergy exclusion [29]. More recently, allergen microarrays, such as ImmunoCAP ISAC (diagnostic testing, Thermo Fisher Scientific, Waltham, MA, USA) or the MeDALL allergen-chip based platforms, have been advanced as excellent tools for the simultaneous detection of multiple allergen-specific IgE towards a large number of clinically relevant allergens [30].

Regarding cashew nut, reports suggest that a wheal diameter over $3 \mathrm{~mm}$ in SPT $[25,31,32]$ and/or a value $\geq 0.35 \mathrm{kUA} / \mathrm{L}$ in immunoCAP FEIA test can be indicative of allergy $[21,25,33]$. Mean values of wheal diameter of $7 \mathrm{~mm}(3-16 \mathrm{~mm})$ and $8.5 \mathrm{~mm}(6.5-10 \mathrm{~mm})$ were reported by Rancé et al. [25] and Clark et al. [31] for children $(<18)$ with medical history of cashew nut allergy. To increase the accuracy of the SPT, the area of the allergen-induced wheal can be compared with the area of a histamine-induced wheal size (as positive control) to correct for skin histamine sensitivity. The ratio is defined as histamine equivalent prick (HEP) index [34]. Considering an average wheal diameter over $3 \mathrm{~mm}$ and HEP index area $\geq 0.4$ as baseline for positive sensitization, van der Valk et al. [32] reported a mean value of 3.02 of HEP index (range 0-15.16) in 164 of cashew nut allergic children.

Using the immunoCAP FEIA test, the mean values for cashew nut-specific IgE described by Rancé et al. [25], van der Valk et al. [32], and Maloney et al. [33] were 3.1, 3.72, and $5.5 \mathrm{kUA} / \mathrm{L}$, respectively. Recombinant Ana o 3 has been reported as a highly accurate diagnostic marker for cashew nut allergy, showing higher sensitivity and specificity levels (93.7 and $94.4 \%$, respectively) over the conventional whole cashew nut extract (95.2 and $58.3 \%$, respectively) [35]. Additionally, the recombinant Ana o 3 was also considered an excellent diagnostic marker for pistachio allergy with similar sensitivity and specificity levels of cashew nut diagnosis. For rAna o 3, an optimal cutoff point of $0.16 \mathrm{kUA} / \mathrm{L}$ was reported as indicative for cashew nut and pistachio allergies [35].

Besides SPT and serum-specific IgE tests, oral provocation tests such as OFC or DBPCFC are considered the "gold standard" tools to identify allergenic foods (e.g. cashew nut) and/or to confirm the allergy [28]. In general, individuals presenting a convincing medical history of cashew nut allergy, SPT of wheal diameter over $3 \mathrm{~mm}$ (HEP index $\geq 0.4$ ) and/or serum-specific IgE of $0.35 \mathrm{kUA} / \mathrm{L}$ are often purposed for oral provocation tests (DBPCFC or OFC) with increasing doses of cashew nut $[32,34]$. The oral provocation tests are normally discontinued and considered positives when objective symptoms occur, when severe subjective symptoms persist $(>1 \mathrm{~h})$ or when subjective symptoms re-appear after second dose of the same challenge material [32]. Patients with negative test 
challenges are frequently advised to introduce cashew nut at home following a defined schedule with increasing doses of the referred nut [32]. Therefore, the correct clinical diagnosis of cashew nut allergy as well as other food allergies should be made considering data from different indicators, namely the medical history, the results from diagnostic testing tools (SPT and serum-specific IgE tests) and food challenges (Fig. 1).

Currently, most food allergic individuals are strongly recommended to follow a prophylactic measure that consists on the total avoidance of the allergenic food. However, accidental exposure to the allergenic food (e.g. cashew nut) or to crossreactive ones is frequently occurring, so therapeutic measures must be applied in those circumstances. Consequently, antihistamines are amongst the most frequently prescribed drugs, followed by epinephrine auto-injectors and systemic corticoids [21, 31]. Amongst cashew nut allergic reactions, the treatment with intramuscular epinephrine is often common owing to the severity of the allergic reactions (anaphylaxis) [31]. Treatment with intramuscular epinephrine (into the midouter thigh) is normally the first line of intervention for the emergency management of an anaphylactic shock [36]. Accordingly, allergic patients at risk of developing anaphylaxis towards cashew nut or other foods are recommended to carry with them an epinephrine auto-injector to be use in case of emergency. This type of auto-injectors (e.g. EpiPen) is normally prepared to release a dose of intramuscular epinephrine, but depending on different factors (e.g. patients' sex, body habitus), the injection might end up being subcutaneous [37]. Despite the fact that in most of the cases the subcutaneous injection of epinephrine is known to work, the administration of subcutaneous or inhaled adrenaline in the treatment of anaphylaxis is not recommended according to recent guidelines [36].
The administration of inhaled short-acting beta- 2 agonists (to relieve symptoms of bronchoconstriction) along with oxygen and fluids can be used as a second line of intervention. Glucocorticosteroids and $\mathrm{H} 1$ and $\mathrm{H} 2$ antihistamines represent the third line of treatment for anaphylaxis. Intravenous or oral glucocorticosteroids are thought to prevent protracted anaphylaxis symptoms, especially in patients with concomitant asthma. The administration of $\mathrm{H} 1$ and $\mathrm{H} 2$ antihistamines is only recommended for the relief of cutaneous symptoms of anaphylaxis (angioedema, urticaria) [36].

More recently, some strategies have been applied aiming at inducing tolerance to different allergens. Immunotherapy has been faced as a potential tool to induce immunomodulation and a desensitisation state in allergic patients, through daily exposure to increasing doses of the offending food. So far, some immunotherapies based on different routes of administration (subcutaneous, epicutaneous, sublingual and oral) have been described for the most common allergenic foods, namely egg, peanut or milk [38-41].

Regarding cashew nut immunotherapy, only few studies could be found in literature, being mostly carried out in animal models (mice). Kulis et al. [42] reported that cashew nut immunotherapy was effective in protecting mice from allergic reactions to cashew nut and had a favourable impact on the walnut challenge in cashew nut/walnut-sensitised mice, leading to a significant decrease of the allergic symptoms. The authors also observed that immunotherapy led to increased cashew nut-specific IgG1 with decreased Th2-type cytokine production, thus suggesting a potential protective role in vivo [42]. In a subsequent study, Kulis et al. [43] proposed the use of pepsinised cashew nut proteins, which elicit weaker allergic reactions, as highly effective immunotherapy reagents for treating cashew nut allergy in mice. Like for immunotherapy

\section{CONFIRMATION OF MEDICAL HISTORY}

\begin{tabular}{l} 
- eliciting allergens \\
- amount of ingested allergenic \\
- tood \\
- syming and chronicity \\
- severity and signs \\
- reproducibility \\
- known risk (co)factors \\
- family history \\
- coexisting medical problems \\
including other allergic diseases \\
\hline
\end{tabular}

Fig. 1 Diagnosis of food (cashew nut) allergy
IGE SENSITIZATION ASSESSMENT

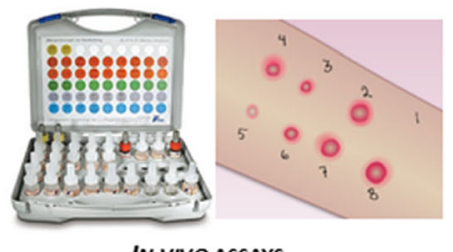

IN VIVO ASSAYS
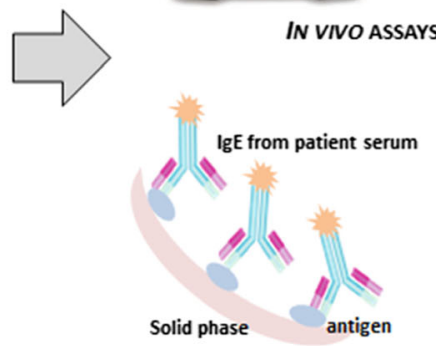

IN VITRO ASSAYS
ORAL FOOD PROVOCATION

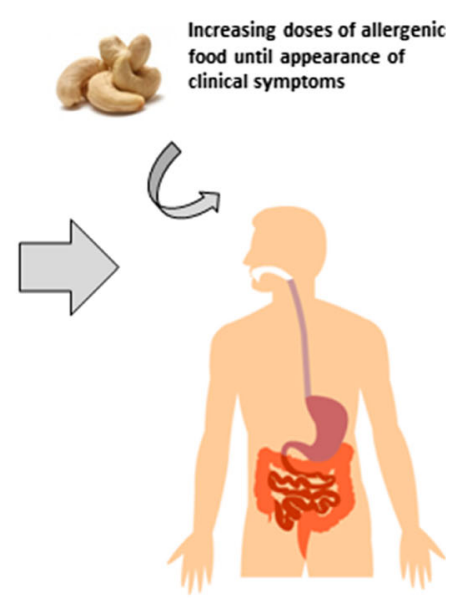


with native cashew nut proteins, in immunotherapy with pepsinised proteins, the levels of $\operatorname{IgG} 1$ and $\operatorname{IgG} 2$ a were increased and the production of Th2-type cytokines decreased [43], thus proposing the use of hypoallergenic cashew nut proteins in allergy treatment.

Information on clinical studies involving the administration of cashew nut to human-allergic patients as immunotherapy is very limited. One of the reports described the application of oral immunotherapy to a 22-year-old man with cashew nut, walnut and peanut allergies, using a daily dose of $0.5 \mathrm{~g}$ of total nut $(0.17 \mathrm{~g}$ of each offending nut) during 8 months. Levels of nut-specific IgE increased in the first month but decreased after 3 and 6 months. The clinical symptoms also decreased in intensity and frequency along the 8-month treatment [44]. The results evidenced the successful use of immunotherapy to induce some tolerance to cashew nut, walnut and peanut allergens upon potential accidental exposure to those nuts.

In a different study that evaluated the ability of omalizumab (anti-IgE) to induce desensitisation to multiple allergens, cashew nut was used as one of the test foods $[45,46]$. Results from phase 1 trials seem to indicate that rush oral immunotherapy to multiple foods with 16 weeks of treatment with omalizumab could allow a fast desensitisation in subjects with multiple food allergies. However, the study is still at a preliminary stage and further understanding about the safety and efficacy parameters of multi-oral immunotherapy experimental treatments with and without omalizumab is much needed [45].

\section{Clinical Threshold Levels for Cashew Nut Allergy}

As part of food allergy diagnosis, individuals with medical history and/or positive results in vitro/in vivo diagnostic tests are often challenged to enter OFC or DBPCFC. From these trials, clinical threshold levels can be characterised for allergenic foods at individual basis [47]. So far, several studies conducted on a variety of allergenic foods evidenced that individual thresholds or lowest observed adverse effect level (LOAEL) vary within food allergic population. Considering that population distribution of minimum eliciting doses (ED) is estimated to be affected by host- (e.g. genetic predisposition, environmental factors), food- (e.g. food processing habits) and population-associated factors (e.g. demographics, geography), the definition of global threshold levels for allergenic foods is difficult to achieve [48]. Nonetheless, the information retrieved from individual threshold levels is foreseen as valuable data for the definition of population threshold levels, thus providing guidance for regulatory and public health agencies, as well as for allergic patients and food industry [47, 49].

Based on OFC and DBPCFC studies, the threshold levels of some allergenic foods (peanut, egg or milk) have been advanced in recent years. However, the determination of cashew nut threshold doses is still at a preliminary stage. In a test population of 31 cashew nut allergic children $(<18$ years $)$, the minimum dose eliciting objective allergic symptoms in $5 \%\left(\mathrm{ED}_{05}\right)$ of the patients corresponded to $7.41 \mathrm{mg}$ of cashew nut protein. When considering any type of symptoms, the $\mathrm{ED}_{05}$ was 23 times lower, being $0.32 \mathrm{mg}$ of cashew nut protein [50].

In a different study using DBPCFC on a test population of 179 children (2-17 years), $1 \mathrm{mg}$ of cashew nut protein was advanced as the minimal eliciting dose for triggering an allergic reaction [32]. Following a revision of allergen reference doses, statistical dose distribution models (log-normal, log-logistic, Weibull) were applied to individual threshold doses for each allergenic food aiming at defining reference doses at population level $[49,51]$. According to the present data of $\mathrm{ED}_{05}$ for cashew nut, a reference dose of $2.0 \mathrm{mg}$ of protein has been provisionally proposed for this allergenic food $[49,51]$. However, until further information regarding individual threshold levels in cashew nut allergic adults is available, Crevel et al. [48] recommend considering the reference dose of $0.1 \mathrm{mg}$ of protein as reference dose for all tree nuts.

\section{Allergen Characterisation and Clinical Relevance}

From the synopsis of allergology and protein evolution, food allergens have been classified as belonging to a few families of proteins, according to their structures and biochemical functions [52]. So far, almost $65 \%$ of the identified plant food allergens are included in four families of proteins (cupin superfamily, prolamin superfamily, Bet v 1-related proteins and profilins) [53].

From an immunological point of view, food allergens can be further categorised as class I or class II, according to their subjacent pattern of sensitisation. Class I food allergens are normally considered as presenting high stability to thermal denaturation, acidic environment and gastrointestinal proteases. Owing to these features, class I food allergens are more likely to function as sensitizer agents through the gastrointestinal tract, being usually responsible for eliciting moderate to severe allergic reactions [54]. Seed storage proteins of the cupin and prolamin superfamilies, namely vicilins, legumins and $2 \mathrm{~S}$ albumins, are examples of class I food allergens $[55,56]$. Class II food allergens present less thermal and digestive stability, thus suggesting that they cannot function as primary sensitizers. As consequence, the route of sensitisation occurs via inhaled allergens that lead to the production of IgE. Class II food allergens are most commonly related to mild clinical manifestations, although moderate or severe symptoms might also occur as consequence of adverse immunological responses to these allergens [54]. In the specific case of cashew nut, the identified allergens are seed storage 
proteins (vicilins, legumins and $2 \mathrm{~S}$ albumins), which are classified as class I food allergens.

In terms of clinical presentation, the reported symptoms of cashew nut allergy are commonly classified as severe and potentially life-threatening, occurring with complex manifestations that often involve more than one target organ/system. Accordingly, most of the allergic reactions to cashew nut evidence skin lesions followed by respiratory and/or gastrointestinal symptoms [57]. Mild clinical symptoms such as oral allergy syndrome are not associated with cashew nut allergy. Within the sphere of clinical manifestations, urticaria and angioedema (cutaneous), abdominal pain and vomiting (gastrointestinal), wheeze, rhino-conjunctivitis, laryngeal oedema and anaphylaxis are amongst the most classical symptoms related to cashew nut allergy [19, 21, 24, 25, 31, 58]. Anaphylaxis is one of the most severe and complex clinical presentation of an allergic reaction since it normally involves several systems (cutaneous, respiratory and cardiovascular). Anaphylaxis is a common clinical presentation of cashew nut allergy similarly to peanut and other nut allergies [24, 57, 58].

So far, three allergenic groups of proteins have been identified and characterised in cashew nut, which have been already included in the World Health Organization/ International Union of Immunological Societies (WHO/ IUIS) official list of allergens [59]. From those, two allergens belong to the cupin (Ana o 1 and Ana o 2) and one to the prolamin (Ana o 3) superfamilies of proteins.

\section{Cupin Superfamily}

The cupin superfamily presents a wide diversity of proteins, which can be found in bacteria and eukaryotes, including plants and animals [60]. Members of this superfamily are characterised by two short conserved consensus sequence motifs and a beta-barrel structural core domain, which is the source of its designation "cupin" [61]. Vicilins and legumins are 7S- and 11S-type globulins, respectively, with two core domains (bicupins), being considered the major seed storage proteins in several nuts and legumes [61]. Like in other nuts, allergenic vicilins and legumins were also identified in cashew nut.

\section{Ana o 1-Vicilin}

Vicilins present a trimeric structure with a total molecular weight of $150-190 \mathrm{kDa}$, being characterised by three subunits of 40 to $80 \mathrm{kDa}$ each [62]. These proteins are composed of $\mathrm{N}$ - and $\mathrm{C}$-terminal domains that are structurally stabilised by non-covalent hydrophobic interactions, hydrogen bonds and van der Waals interactions. Vicilins are glycosylated, presenting one or two N-linked glycosylation sites at the C-terminal domain, which seem to have a significant stabilising effect on protein structure [61].
Ana o 1 are the allergenic vicilins identified and characterised in cashew nut $[59,63]$, encompassing two isoforms (proteins with more than $90 \%$ of sequence identity) [64]: Ana o 1.0101 and Ana 1.0102 with 538 and 536 amino acids (aa), encoded by mRNA sequences of 1810 and $1660 \mathrm{bp}$, respectively (Table 2). Using competent Escherichia coli BL21 (DE3) cells, Wang et al. [65] were able to express recombinant Ana o 1.0101 and Ana o 1.0102 with molecular sizes of 65 and $55 \mathrm{kDa}$, respectively, after digestion with thrombin to separate the $43-\mathrm{kDa}$ maltose-binding protein from the expressed fusion proteins. Sequence identity and similarity with other vicilins (oil palm, macadamia nut and walnut) were in the ranges of 33-40 and $54-59 \%$, respectively. The IgE-binding capacity of these recombinant proteins was further evaluated by immunoblotting with sera from cashew nut allergic patients. As a result, 10 out the 20 sera from cashew nut allergic patients $(50 \%)$ were IgEreactive to the recombinant proteins, thus suggesting that Ana o 1 is a major allergen in cashew nut [65]. In the same study, the authors also sequenced possible epitopes for Ana o 1 and evaluated their IgE reactivity with three sets of pooled sera from different cashew nut allergic patients. From the 11 peptides covering the entire length of the protein, three were strongly immunoreactive, indicating that they are most likely immunodominant epitopes [65]. Using the same procedure to obtain a recombinant Ana o 1, Guan et al. [66] demonstrated that two of the linear epitope-contributing peptide segments, which were previously reported by Wang et al. [65], participate in a conformational epitope. Additionally, the authors also revealed three new peptide segments that are believed to function as independent linear epitopes when complexed with some antibodies and/or together, contributing to one or more conformational epitopes [66].

More recently, Reitsma et al. [67] were able to extract and purify native Ana o 1, Ana o 2 and Ana o 3 allergens from defatted cashew nut flour. Using non-reducing denaturing conditions by SDS-PAGE and further confirmed by matrixassisted laser desorption/ionisation-tandem mass spectrometry (MALDI-MS/MS), Ana o 1 was identified as a single protein of $50 \mathrm{kDa}$ or as a dimer of $100 \mathrm{kDa}$. The predicted glycosylation of Ana o 1 was also confirmed by glycoprotein staining. Besides some cross-reactivity between Ana o 1 and Ana o 2 (both globulins), minor unexpected cross-reactivity was observed between Ana o 1 and Ana o 3 allergens [67].

Using molecular modelling, Barre et al. [68] proposed three-dimensional (3D) models for allergenic vicilins of peanut (Ara h 1), walnut (Jug r 2), hazelnut (Cor a 11) and cashew nut (Ana o 1). 3D models built for the Jug $r$ 2, Cor a 11 and Ana o 1 monomers exhibit an overall cupin fold very similar to that of beta-conglycinin (soybean), by presenting a cupin motif made of two tandemly arrayed modules. When comparing linear epitopes, Ana o 1 exhibited homology with Ara h 1 and beta-conglycinin, but the highest epitope homology was observed with vicilins from other nuts, namely Cor a 11 
(hazelnut) and Jug r 2 (walnut) [68]. In in vivo cross-reactivity assays, cashew nut-sensitised mice reacted to $1 \mathrm{mg}$ of walnut almost as strongly as to the same quantity of cashew nut, often experiencing severe anaphylactic reactions.

Clinical symptoms were weaker in cashew nut-sensitised mice upon challenging with $1 \mathrm{mg}$ of peanut than with equal amounts of cashew nut or walnut, although symptoms increased in intensity depending on the dose of peanut used for the challenge. As a result, Jug r 2 and Ara h 1 were the cross-reactive allergens implicated in the allergic responses triggered in cashew nut-sensitised mice [69]. Contrarily to a previous report stating that there was no cross-reactivity between cashew nut and peanut allergens [70], Ana o 1 was also found to be IgE-reactive with human sera of peanutallergic patients, thus suggesting cross-reactivity between Ara h 1 and Ana o 1 allergens [68]. Strong cross-reactivity of cashew nut with pistachio (both members of the Anacardiaceae family) has been previously described in cashew nut and/or pistachio-allergic patients [71-73]. Confirming these clinical evidences, a high overall identity (80\%) and similarity $(90 \%)$ were found between the primary sequences of Ana o 1 and Pis v 3 (pistachio), with Pis v 3 sharing high homology in two of the Ana o 1 immunodominant peptides $[74,75]$. In some cashew nut/pistachio allergic patients, cashew nut seems to act as the primary sensitizer agent in both cashew nut and pistachio allergies [75].

Ana o 2-Legumin

The legumins or 11S globulins are a different class of functional proteins that belong to the cupin superfamily. Legumins are multimeric proteins that exist as a mixture of trimers and hexamers of $50-60 \mathrm{kDa}$ linked by non-covalent interactions [76]. Each monomer results from the expression of multiple genes and is synthesised as a single polypeptide, which is then post-translationally cleaved into two polypeptides-one acidic $(30-40 \mathrm{kDa})$ and one basic $(\sim 20 \mathrm{kDa})$ - linked by a disulphide bond. Contrarily to vicilins, legumins are normally non-glycosylated proteins. Legumins are seed storage proteins, representing more than $50 \%$ of protein fraction in several nuts and legumes [76].

Ana o 2 is the allergenic legumin identified and characterised in cashew nut $[59,63]$, comprising one isoform: Ana o 2.0101 with 457 aa and a molecular size of approximately $55 \mathrm{kDa}$, which is encoded by a mRNA sequence of 1671 bp (Table 2). Upon characterisation of the soluble protein fraction of cashew nut, Teuber et al. [77] identified the heavy chain of a legumin that present high $\operatorname{IgE}$ reactivity $(>50 \%)$ with sera from cashew nut allergic patients. Accordingly, the protein was designated as Ana o 2 and classified as a major allergen in cashew nut [77]. Native Ana o 2 was isolated presenting bands of 33, 53 and $120 \mathrm{kDa}$, which were estimated to correspond to a heavy chain polypeptide, a 
monomer and a dimer of legumin, respectively [78]. Using non-reducing denaturing conditions by SDS-PAGE and MALDI-MS/MS, 53-, 30- and 21-kDa bands of Ana o 2 were confirmed as the complete protein (monomer), large subunit and small subunit, respectively [67].

Like for the Ana o 1 allergen [65], the recombinant Ana o 2 was also expressed by competent $E$. coli BL21 (DE3) cells as a $93-\mathrm{kDa}$ fusion protein with a $43-\mathrm{kDa}$ maltose-binding protein [78]. Sequence identity and similarity were in ranges of 42-58 and 58-74\%, respectively, with different allergenic 11S globulins, namely Cor a 9 (hazelnut), Jug r 4 (walnut), Ara h 3 (peanut), Ses i 7 (sesame) and Gly $\mathrm{m} 6$ (soybean) amongst others $[78,79]$. The IgE-binding capacity of recombinant Ana o 2 was further evaluated by immunoblotting with sera from 21 cashew nut allergic patients with clear history of life-threatening adverse responses to cashew nut. The sera from 13 patients were IgE-reactive to recombinant Ana o 2, which represents $62 \%$ of the test population [78], thus confirming its previous classification as a major allergen of cashew nut [77]. In the same study, Ana o 2 was sequenced to determine possible $\operatorname{IgE}$ epitopes against pooled sera from different cashew nut allergic patients. From a total of seven epitopes that were strongly IgE-reactive (potential immunodominant epitopes), six epitopes were located in the acidic polypeptide [78], suggesting that this region might be predominantly related to allergenicity.

Linear IgE-binding epitopes were mapped from 3D models of Ana o 2 (cashew nut), Jug $r 4$ (walnut), Cor a 9 (hazelnut) and Ara h 3 (peanut) obtained by homology modelling [80]. Based on the 3D model of Ana o 2, three linear epitopes were identified on its surface, most of those containing positively or negatively charged residues, which were predominantly located on the acidic face of Ana o 2 trimer. Epitope no. 13 of Ana o 2 overlaps with one epitope (epitope no. 3) of Ara h 3 (peanut). Both epitopes form a strongly charged area on the molecular surface of the corresponding allergens and exhibit a rather conserved overall conformation, despite the moderate degree of amino acid sequence identity [80]. These common structural features seem to indicate that linear IgE-binding epitope no. 13 of Ana o 2 corresponds to a consensual epitope that also occurs in other nut (Ara h 3, Cor a 9 and Jug r 4) and plant (G2-glycinin) legumins [79, 80]. Additionally, Ana o 2 displays some exposed residues belonging to linear epitopes that are predicted to participate in conformational epitopes. This is the case of some exposed residues of epitope no. 13, no. 5 and no. 9 that are estimated to be part of a conformational epitope. Likewise, some residues from epitope no. 21 and no. 22 are also predicted to participate in a unique conformational epitope located at one extremity of the Ana o 2 protomer [80]. More recently, Robotham et al. [81] confirmed the first Ana o 2 conformational epitope by reactivity with monoclonal antibody $2 \mathrm{~B} 5$, which is located on the large subunit and it is structurally dependent upon association with the small subunit.
With respect to this conformational epitope, both native and recombinant Ana o 2 reacted similarly upon denaturation despite the structural differences between forms [81, 82].

Lately, Kshirsagar et al. [83] estimated the native secondary structure of anacardein (Ana o 2) with $49 \%$ of beta-sheets, $23.7 \%$ of alpha-helices and $27.4 \%$ of random coil (absence of regular secondary structure). Different denaturing conditions (guanidine- $\mathrm{HCl}$, urea, sodium dodecyl sulphate, beta-mercaptoethanol and heat $-100{ }^{\circ} \mathrm{C}, 5 \mathrm{~min}$ ) were used to assess the effect of structural changes on the immunoreactivity of anacardein (Ana o 2). As a result, denaturing treatments with sodium dodecyl sulphate or beta-mercaptoethanol induced conformational changes, causing a significant reduction in the immunoreactivity of anacardein when tested with an antibody that target conformational epitopes [83]. The addition of oleic acid to Ana o 2 at a concentration of $5 \mathrm{mM}$ and overnight incubation at $37{ }^{\circ} \mathrm{C}$ induced a $35 \%$ reduction of the IgE-binding capacity of Ana o 2. This fact seems to suggest that the oleic acid can reduce the allergenic properties of cashew nut by binding to its major protein Ana o 2 [84].

\section{Prolamin Superfamily}

The prolamin superfamily is one of the most relevant families of proteins since it encompasses a great number of allergenic members. Common features, such as the presence of eight conserved residues of cysteine, high content in proline and glutamine residues (source of its denomination), low molecular weight, similar conformational structures rich in alphahelices and great stability to thermal processing/proteolysis, are shared by the members of this superfamily [60]. Contrarily to legumes and nuts, prolamins are the main storage proteins in most cereal grains (except in rice and oat) and members of the grass family $[60,85]$. The members of this superfamily include the $2 \mathrm{~S}$ albumin seed storage proteins, the non-specific lipid transfer proteins and the cereal seed inhibitors of alphaamylase and trypsin [62].

\section{Ana o 3-2S Albumin}

$2 \mathrm{~S}$ albumins represent a family of water-soluble proteins at low-salt concentrations, presenting a primary structure with high content in arginine, glutamine, asparagine and cysteine residues, sharing the same common features of prolamin members [86]. They are small globular proteins with $12-15 \mathrm{kDa}$ that undergo sequence modifications after synthesis. Mature $2 \mathrm{~S}$ albumins are composed by heterodimers, consisting of a large $(8-10 \mathrm{kDa})$ and a small (3-4 kDa) subunits linked by two conserved inter-chain disulphide bonds $[62,87,88]$. These proteins have two additional intra-chain disulphide bonds, which stabilise and compact their structure. Besides intervening in seed 
germination most likely as nitrogen and sulphur donors, some $2 \mathrm{~S}$ albumins are also known to act as antifungal agents, as serine protease inhibitors and as calmodulin antagonists [89, 90]. They are considered an important family of proteins since they are responsible for most plant food allergies [91].

Ana o 3 is the allergenic $2 \mathrm{~S}$ albumin identified and characterised in cashew nut $[59,63]$. So far, one isoform, Ana o 3.0101, has been identified in cashew nut presenting 138 aa and a molecular size of approximately $14 \mathrm{kDa}$, which is encoded by a mRNA sequence of $585 \mathrm{bp}$ (Table 2). Besides identifying a vicilin (Ana o 1) and a legumin (Ana o 2) in the soluble protein fraction of cashew nut, Teuber et al. [77] also isolated three small proteins with molecular sizes below $14 \mathrm{kDa}$ (estimated to correspond to a large subunit) that were classified as $2 \mathrm{~S}$ albumins. Owing to their high immunoreactivity with sera from cashew nut allergic patients $(>73 \%)$, these proteins were classified as major allergens, being designated as Ana o 3 [77]. Using competent $E$. coli BL21 (DE3) cells, Robotham et al. [92] identified a recombinant Ana o 3 after the purification of the fusion protein $(57 \mathrm{kDa})$ with a 43-kDa maltose-binding protein. The primary structure of Ana o 3 was evaluated with known sequences of other nut $2 \mathrm{~S}$ albumins, revealing high degree of identity and similarity with Pis v 1 (pistachio), Jug n 1 (black walnut), Jug r 1 (English walnut) and Car i 1 (pecan nut), amongst others [92, 93]. Ana o 3 evidenced strong IgE reactivity with sera from 21 out of 26 patients with clear medical history of moderate to severe allergic reactions upon cashew nut ingestion [92], thus confirming its previous classification as major allergen [77].

More recently, Reitsma et al. [67] evaluated Ana o 3 by SDS-PAGE in denaturing reducing conditions, allowing detecting three distinct bands at 10, 8 and $6 \mathrm{kDa}$. Native and denatured reduced Ana o 3 triplet was further analysed by liquid chromatography-mass spectrometry (LC-MS). The bands of 10 and $8 \mathrm{kDa}$ were identified as the large subunit presenting 8.2-8.4 and 8.1-8.2 kDa, respectively. The band of $6 \mathrm{kDa}$ was recognised as the small subunit of $3.7-4.5 \mathrm{kDa}$ [67]. Contrarily to Robotham et al. [92], who described that all three bands were isoforms of the large subunit of Ana o 3 with very similar N-terminal sequences, Reitsma et al. [67] evidenced that the small and the large subunits of Ana o 3 presented $\mathrm{N}$ - and $\mathrm{C}$-terminal micro-heterogeneity and $\mathrm{C}$-terminal micro-heterogeneity, respectively. This feature is also common to other allergenic $2 \mathrm{~S}$ albumins, namely in Ber e 1 (Brazil nut) and Ses i 1 (sesame) [94, 95]. After sequencing, epitope mapping of Ana o 3 was performed using the sera of 4 cashew nut allergic patients in a total of 42 overlapping peptides, covering the entire length of the protein. From those, 12 peptides were IgE-reactive to the serum of at least one cashew nut allergic patient, with the most strongly reactive peptides being located at the large subunit of Ana o 3 [67].

\section{Effect of Processing and Digestibility on Cashew Nut Allergens}

Presently, there is a wide variety of technologies available for food processing aiming at improving the organoleptic attributes and/or shelf-life of the product, which is mostly achieved by removing/inactivating microbial activity and by altering the properties of different food components [96]. Accordingly, proteins involved in sensitising/eliciting allergic reactions may undergo extensive modification during food processing and/or may be present within complex structures in food. Due to the diversified nature of the allergenic proteins (e.g. albumins, vicilins, legumins, profilins, nsLTP), their immunoreactivity is associated with the presence of conformational and/or linear epitopes $[97,98]$. If on one side some thermal treatments are known to reduce the immunoreactivity of proteins, such as profilins and vicilins, the same processes cause no effect on proteins, such as $2 \mathrm{~S}$ albumins or legumins [98]. On the other side, the formation of novel IgE-binding sites as a consequence of allergen unfolding (thermal treatment) or chemical/enzymatic modifications can increase their immunoreactivity [97].

In the specific case of cashew nut, few reports describing the effect of different food processing treatments on its immunoreactivity are available in the literature $[70,99,100]$. de Leon et al. [70] assessed the effect of roasting (thermal treatment) on the immunoreactivity of cashew nut, verifying that roasting at $180^{\circ} \mathrm{C}$ for $15 \mathrm{~min}$ did not affect the IgE-binding capacity of cashew nut allergens. Su et al. [99] evaluated the effect of other processing treatments, namely the application of gamma irradiation or thermal conditions and the combination of both, on the immunoreactivity of cashew nut allergens. From different thermal conditions that included autoclaving, blanching, frying, microwave and roasting, varying the time and temperature in each of the procedures, only roasting at $160{ }^{\circ} \mathrm{C}$ for $30 \mathrm{~min}$ reduced IgE-binding of Ana o 2 with rabbit anti-cashew nut polyclonal antibodies. IgE reactivity was also strongly reduced in cashew nut subjected to gamma irradiation at $25 \mathrm{kGy}$ followed by autoclaving at $121{ }^{\circ} \mathrm{C}$ during $30 \mathrm{~min}$ [99].

Venkatachalam et al. [100] also tested the effect of different thermal (autoclaving, blanching, microwave heating and dry roasting - varying time/temperature) and $\mathrm{pH}(1,3,5,7,9,11$ and 13) conditions as well as gamma irradiation (1-25 kGy) on the immunoreactivity of cashew nut allergens (Ana o 1, Ana o 2 and Ana o 3). Two monoclonal antibodies ( $\mathrm{mAb} 4 \mathrm{~B} 7$ and $\mathrm{mAb} 1 \mathrm{H} 2$ ) were used to evaluate the reactivity of Ana $\mathrm{o} 1$. In samples submitted to thermal treatments, the monoclonal antibody (mAb 4B7) did not detect any band at $\sim 50 \mathrm{kDa}$, although the immunoreactivity was not considerably affected by gamma irradiation. Contrarily, using the monoclonal antibody $(\mathrm{mAb} 1 \mathrm{H} 2)$, Ana o 1 was detected in all samples, although the intensity of the IgE-binding was decreased in the 
sample autoclaved for $20 \mathrm{~min}$. Therefore, Ana o 1 is most likely to lose its conformational structure upon heat treatments, although preserving linear epitopes that remain IgE-reactive. Ana o 1 seems to be stable to $\mathrm{pH}$ alterations since immunoreactivity was only affected in the sample submitted to $\mathrm{pH}$ 13. However, the significance of Ana o 1 instability at this level of $\mathrm{pH}$ is minimal, considering that most methods for cashew nut processing do not use $\mathrm{pH} 13$ [100].

The immunoreactivity of Ana o 2 after processing simulations was also assessed by one polyclonal (pAb) and two monoclonal (mAb $4 \mathrm{C} 3$ and mAb $4 \mathrm{H} 9)$ antibodies. Extreme processing conditions (e.g. autoclaving for $30 \mathrm{~min}$ or $\mathrm{pH} 1$ ) seemed to enable minor reductions on the IgE reactivity by pAb-based ELISA (enzyme-linked immunosorbent assay). The immunoreactivity of Ana o 2 using mAb $4 \mathrm{H} 9$ or mAb $4 \mathrm{C} 3$ was very similar to the results from $\mathrm{pAb}$, with minor IgEbinding reduction at extreme $\mathrm{pH}$ conditions ( $\mathrm{pH} \mathrm{1-3}$ or 13). Regardless the type of assay or antibody used, Ana o 2 seems to preserve its structural integrity, which is normally expected in this family of proteins (legumins) [100].

The monoclonal antibody (mAb D2) used for Ana o 3 recognition did not bind any of its known linear epitopes, suggesting that it probably recognises a conformational epitope or a potential linear motif that has not yet been identified in this allergen. Ana o 3 is stable to a $\mathrm{pH}$ range of $1-11$ but not detectable at $\mathrm{pH} 13$. Thermal processing, such as autoclaving, blanching or roasting for $10 \mathrm{~min}$, significantly decreased the immunoreactivity of Ana o 3 when tested with $\mathrm{mAb}$ D2 by ELISA, which might be related to some structural alterations (e.g. denaturation) of Ana o 3 [100].

In spite of the distinct nature of cashew nut allergens (vicilin, legumin and $2 \mathrm{~S}$ albumin), the majority of the processing conditions did not affect or have little effect on the allergenicity of Ana o 1, Ana o 2 and Ana o 3. These results seem to confirm their great potential for eliciting adverse immunological responses in sensitised/allergic patients, even after extensive food processing. Moreover, a general increase in the intensity of the bands, which is an indicative of increased immunoreactivity, was observed in samples subjected to roasting at $170{ }^{\circ} \mathrm{C}$ for $20 \mathrm{~min}$. These results might also indicate that some processing conditions can contribute to increase, rather than reduce, the immunoreactivity of cashew nut allergens [100].

More recently, Mattison et al. [101] reported that treating cashew nut with sodium sulphite disrupted the conformational structure of Ana o 3, in a temperature-dependent manner. The structural integrity of Ana o 2 was also disrupted in cashew nut extracts treated with high concentrations of sodium sulphite $(\geq 50 \mathrm{mM})$ at high temperatures $\left(\geq 100^{\circ} \mathrm{C}\right)$. In general, the immunoreactivity of Ana o 2 and Ana o 3 was greatly reduced with high concentrations of sodium sulphite $(\geq 50 \mathrm{mM})$ and high temperatures $\left(\geq 100{ }^{\circ} \mathrm{C}\right)$. In the same study, the authors suggest that sulphating agents (e.g. sodium sulphite) seem to act at multiple levels in the reduction of IgEbinding to allergens. Accordingly, by targeting the disulphide bonds and negatively charging the thiol group, conformational epitopes are destroyed and linear ones with charged thiols are most likely to be repelled from IgE-binding sites. As a result, the incorporation of sodium sulphite or other food-grade reagents with similar redox potential may be useful to reduce or eliminate the allergenicity of some proteins [101].

Based on current knowledge relating to gastrointestinal digestion and food allergies, in vitro assays simulating the in vivo digestion have been used as predictive tools to assess the allergenic potential of novel food proteins [102]. In spite of the increasing number of works detailing the effect of the simulated gastrointestinal digestion on specific allergenic foods (e.g. milk, egg, crustaceans), only a report could be found targeting cashew nut allergens. To mimic the gastric and intestinal digestion of cashew nut proteins, Mattison et al. [103] used in vitro assays to assess the effect of gastric and intestinal fluids on defatted cashew nut flour. Some Ana o 2 peptides were resistant to digestion and remained immunoreactive, whilst Ana o 3 peptides seemed to lose some capacity to bind IgE. However, the study also suggested that Ana o 3 was only partially digested. Ana o 3 is most likely to resist to both gastric and intestinal digestion, which is consistent with the stability of other $2 \mathrm{~S}$ albumins, thus preserving their immunoreactivity when reaching the lumen [103].

\section{Management and Traceability of Cashew Nut}

Food allergies are considered as an important public health problem with major impact on the quality of life of sensitised/allergic individuals [104], representing a current societal challenge. Faced as a multidisciplinary task, the management of food allergies requires the involvement of multiple actors, namely regulatory authorities, different stakeholders (food industry, clinicians and caretakers) and sensitised/ allergic consumers [105]. Acting at different levels, all entities share a common feature of protecting the health of sensitised/ allergic individuals. The regulatory authorities and food industry operate at population level, being responsible for guaranteeing the protection of public health and for providing safe foods for all intended consumers, respectively. However, the ultimate responsibility lies at the individual level, specifically on the sensitised/allergic consumers, since they are accountable for all preventive measures regarding the total avoidance of the allergenic food (and/or cross-reactive ones) [105]. Therefore, the allergic consumers are fully dependent on the label information of processed foods, whilst carefully selecting their nutrient sources. According to recent legislation, ingredients belonging to the 14 groups of potentially allergenic foods must be highlighted in the label through a typeset (font, style or background colour) that clearly 
distinguishes them from the rest of the list of ingredients, independently of their quantity $[11,12]$.

Currently, food industry practices precautionary labelling (e.g. may contain traces of cashew nut) under global legal directives [11, 12]; therefore, most of the allergic individuals are protected against the consumption of allergenic foods [106]. However, accidental exposure to hidden allergens in foods owing to mislabelling or cross-contaminations during food processing (e.g. shared production lines) constitutes a real risk for allergic consumers [107, 108]. To avoid potential health risks, proper and highly sensitive analytical methodologies represent essential assets to aid the industrial management of allergenic foods and subsequently to facilitate allergen control/monitoring by the regulatory authorities.

Despite some contradictory opinions regarding the best target analyte for allergen detection/quantification in foods, there is a wide spectrum of analytical methods based on proteins and/or DNA analysis for most of the allergenic food commodities. Nonetheless, the lack of available official methods and testing/reference materials for their detection/quantification represents a major shortcoming in food allergen management $[107,108]$. The choice of the best method for allergen analysis depends on specific criteria, such as target analyte (proteins versus DNA), basis of detection (e.g. chemical), cost per run/ analysis, setup cost, cross-reactivity, the need for expertise knowledge and possibility for multi-target detection [109]. For cashew nut analysis, there are several commercial and in-house-based methods either targeting allergenic/marker proteins or respective encoding DNA (Fig. 2).

\section{Protein-Based Methods}

Considering the advantages and drawbacks associated with all analytical methods, the classical protein-based methods (lateral flow devices (LFD), dipstick tests, ELISA, immunoblotting) are the most commonly used for food allergen analysis. However, other cutting-edge technologies, such as the immunosensors and the MS platforms, have also been developed and applied to allergen detection/quantification in foods.

\section{ELISA and LFD}

Based on typical antigen-antibody interaction, ELISA and LFD offer good sensitivity, adequate specificity and simple sample handling. ELISA are considered semi-quantitative or quantitative tools, being the most widely used analytical

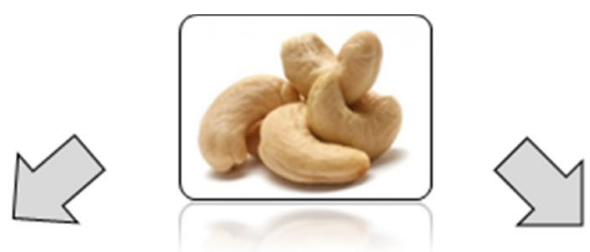

Protein-BASED MethodS

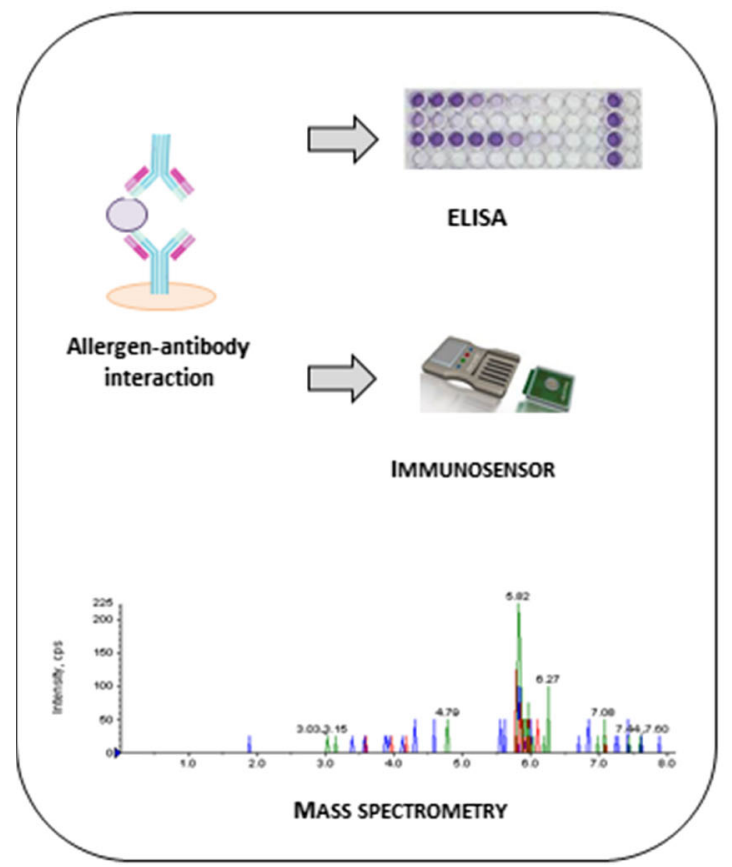

DNA-BASED MethodS

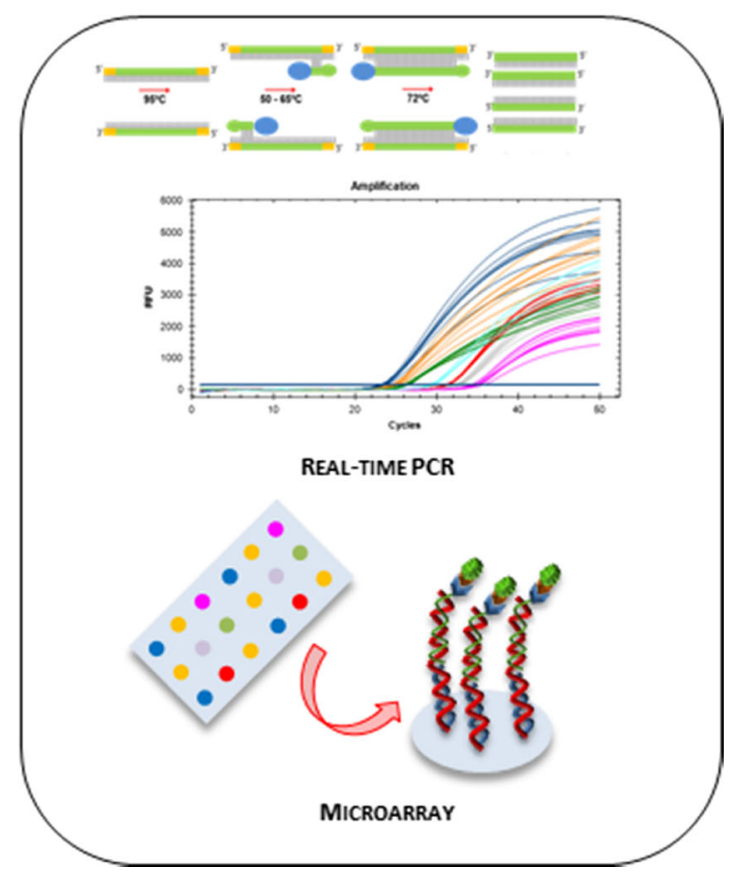

Fig. 2 Representative protein- and DNA-based methods for the detection and quantification of cashew nut allergens in foods 
technique for routine analysis and screening of allergens in foods [110]. LFD are simplified versions of ELISA [110], which are also quite popular in the food industry, being commonly used to check potential cross-contaminations along the production lines or in the final formulations [107].

Presently, ELISA kits and LFD can be commercially acquired, enabling the detection of a great number of different allergenic foods. Table 3 summaries the available ELISA kits and LFD for the specific detection of cashew nut in foods. These assays can be applied to a wide spectrum of food matrices with alleged sensitivities of $1-2$ or $0.2-1 \mathrm{mg} / \mathrm{kg}$ of cashew nut in foods by LFD or ELISA, respectively. However, as expected for this type of assays, some cross-reactivity occurs between cashew nut and other plants, namely with Brazil nut, pistachio, hazelnut, peanut and walnut (Table 3).

Besides commercial kits, some in-house developed ELISA have been proposed for the detection of cashew nut in complex and processed food matrices, namely spices, cereals, chocolates, ice creams and cookies (Table 4). ELISA sandwich type is the most commonly applied, although other formats can be used (e.g. direct ELISA, indirect ELISA, competitive ELISA). The reported limits of detection (LOD) for these assays are aligned with commercial kits, ranging from 0.1 to $1.0 \mathrm{mg} / \mathrm{kg}$ depending on the type of food matrix [111-116]. ELISA systems can also be performed as a multi-target approach using the combination of different antibodies in single assays. Accordingly, an indirect multi-target ELISA was successfully proposed by Rejeb et al. [115] for the simultaneous detection of peanut and four nuts (cashew nut, almond, hazelnut and Brazil nut) in milk and dark chocolates (Table 4). In the reported study, the multi-target ELISA enabled detecting down to $1 \mathrm{mg} / \mathrm{kg}$ of cashew nut in milk and dark chocolates [115].

A different commercial immunoassay based on magnetic beads was performed by Cho et al. [116] for the simultaneous detection of 14 allergenic foods plus gluten. In the described method, each allergenic food was combined with microspheres and targeted by two capture antibodies, detecting raw cashew nut with some cross-reactivity towards hazelnut, pistachio and Brazil nut.

In spite of all the advantages attributed to immunoassays, there are several drawbacks that cannot be ruled out. Both LFD and ELISA are prone to cross-reactivity issues that might occur from matrix effects that lead to false positive results and, upon harsh food processing conditions (heat treatments, glycation, $\mathrm{pH}$ alterations, formation of Maillard products, fermentation, partial hydrolysis), false negative results are likely to occur [107].

\section{Immunosensors}

Presently, a great attention has been devoted to biosensing technology, being regarded as one of the most promising approaches for fast, reproducible, simple and low-cost multi- target analysis of food allergens. Along with their potential for automation and high speed of execution, biosensors have been faced as tools with great potential for real-time allergen monitoring at an industrial scale [121]. In concept, biosensors are based on the direct recognition of a biological interaction between a receptor and a target molecule (proteins or DNA) by means of a transducer that produces a measurable signal $[110,122]$. This interaction can be registered by different transducers (optical, piezoelectric or electrochemical) that are capable of acquiring the signal and further process it to give a proportional output to the concentration of a specific target [110].

So far, some biosensors using antibodies as biological receptors (also known as immunosensors) have been suggested for food allergen analysis [123]. Rebe Raz et al. [117] developed a sensor chip as a multi-target approach for the detection of 12 allergenic foods, including cashew nut. The antibodies targeting each allergenic food were immobilised onto a sensor chip as a microarray platform, and the signal acquisition was performed by an optical transducer (imaging surface plasmon resonance - iSPR) without requiring labelling or signal amplification. In the proposed microarray, it was possible to detect cashew nut down to 0.4 and $0.9 \mathrm{mg} / \mathrm{kg}$ in cookies and chocolates, respectively (Table 4). The sensitivity of the immunosensor was in the same range of the ELISA kits (Table 3) and of the inhouse developed ELISA (Table 4), being suggested as excellent alternatives for multi-target allergen detection.

\section{Mass Spectrometry}

The continuous and rapid evolution of proteomic approaches has turned them as efficient tools for the characterisation of food-derived proteins. Owing to the impressive increase in the performance and versatility of MS instrumentation, the development of novel analytical strategies for the identification, characterisation and determination of allergens represents a valuable platform for food allergenomics [124-126]. MS platforms are normally coupled to a LC system that counts several advantages, such as high accuracy, sensitivity, specificity and reproducibility, which have greatly contributed for their application in the field of food allergen analysis [126, 127]. In addition, MS technology allows direct detection of the target peptide/protein without requiring an interaction with a biological receptor (e.g. antibody), which eliminates the problem related to cross-reactivity phenomena and enables the unequivocal identification of target analytes [126].

So far, three MS-based applications have been reported for the detection and quantification of cashew nut in foods, which are listed in Table 4. The methods were developed as multitarget approaches, enabling cashew nut identification and discrimination from other nuts (e.g. almond, walnut, hazelnut) in different food matrices (biscuits, chocolates, cookies, cakes and flours) [118-120]. At least, two marker peptides from 


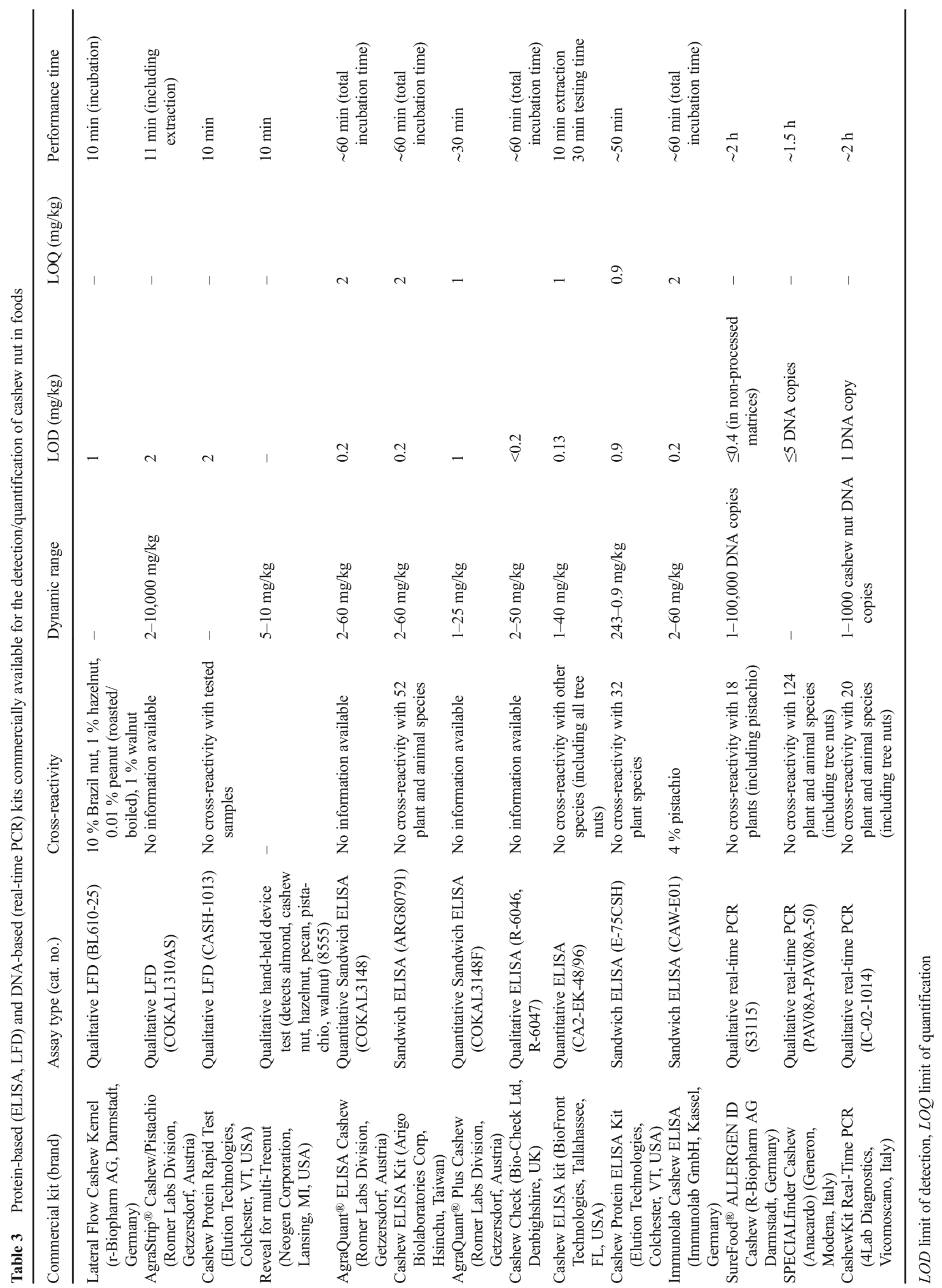




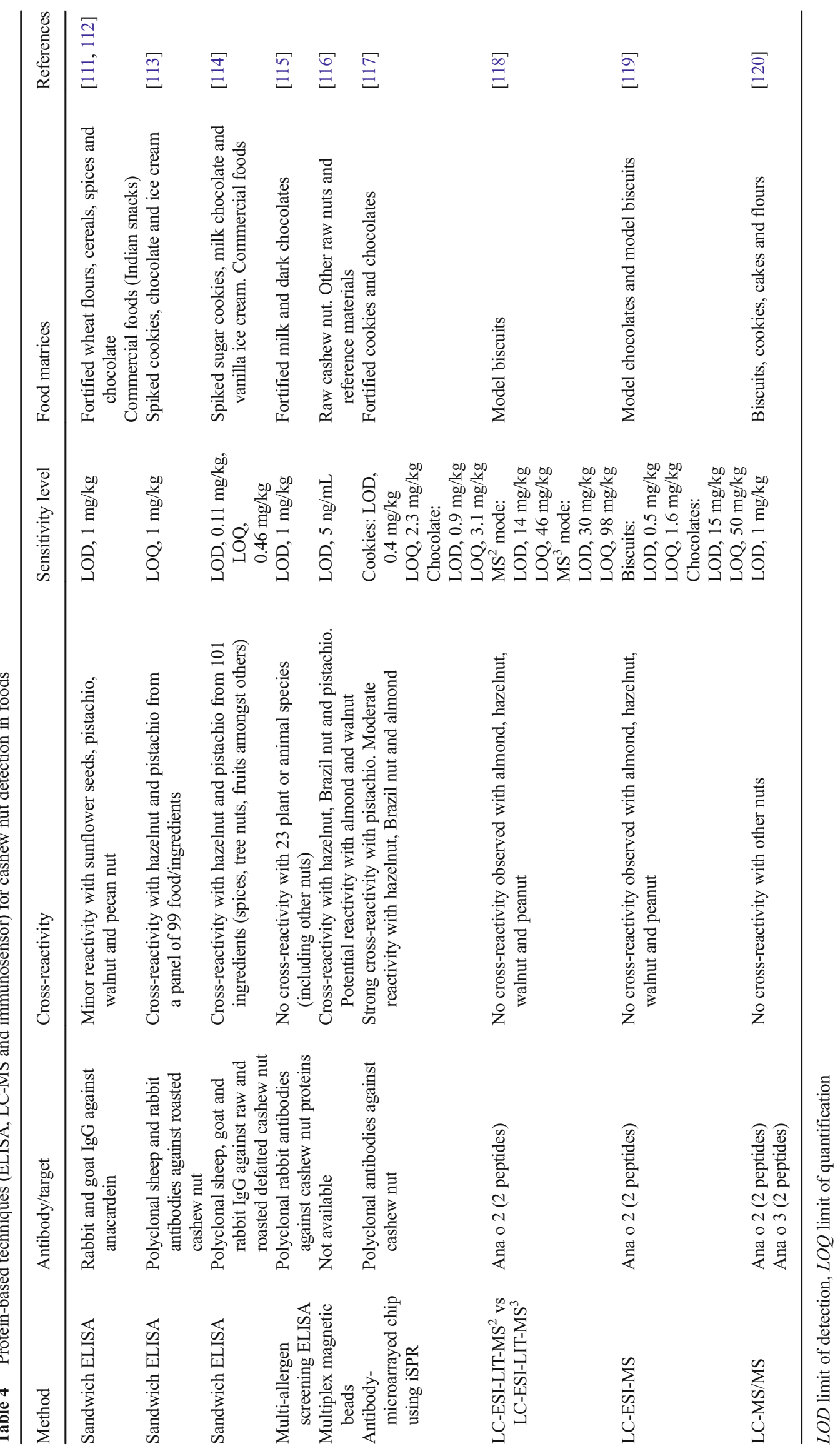


allergenic proteins (Ana o 2, Ana o 3) of cashew nut were used for its unequivocal identification, showing no cross-reactivity phenomena with peptides from different nuts (Table 4). In general, the limits of detection and quantification $(0.5-100 \mathrm{mg} / \mathrm{kg})$ proposed by the MS methods were higher than those reported for ELISA kits $(0.2-1 \mathrm{mg} / \mathrm{kg}$ ) (Table 3) or in-house developed ELISA (0.1-1 mg/kg) (Table 4). Like for other protein-based methods (e.g. ELISA), the sensitivity attained with MS approaches was also affected by the food matrix (Table 4). Accordingly, LOD and LOQ were considerably higher when targeting cashew nut in difficult food matrices (such as chocolates) than in cookies/biscuits [119]. MS-based methods are excellent alternatives for direct allergen detection/quantification, but the high cost of MS platform maintenance/equipment and the need for specialised personnel are main factors to consider.

\section{DNA-Based Methods}

Presently, methodologies based on the detection of DNA for food allergen analysis have been regarded with increasing interest. DNA molecules are more likely to preserve their integrity upon harsh food processing conditions, when compared to proteins. Therefore, DNA-based methods have proved to be excellent alternatives to protein-based methods, especially when analysing highly processed foods. In spite of being considered as indirect approaches for allergen detection, DNA-based tools can be easily implemented in routine analyses and considered, at the same time, as confirmatory tools for the identification of allergenic commodities [107, 108, 128]. In recent years, DNA-based methods have emerged, demonstrating their potentialities for food allergen analysis.

\section{Real-Time PCR}

Methods based on the polymerase chain reaction (PCR) are amongst the most commonly used DNA approaches for food allergen analysis. With adequate setup cost, reasonable running time and moderate requirements for specialised equipment and personnel, PCR systems can be used for quantification purposes (e.g. real-time PCR). PCR-based techniques are also less prone to cross-reactivity phenomena by carefully selecting the target sequence [107, 108], thus being independent of possible biological effects associated with antibody production.

Presently, some real-time PCR kits can be commercially acquired for food allergen analysis, although at a much smaller scale than the immunoassays (e.g. ELISA or LFD). Table 3 summarises most of the available real-time PCR kits for the specific detection of cashew nut in foods. These kits can be tested in a variety of foods with sensitivities that are strongly dependent on the type of food matrix analysed. Nonetheless, the listed kits allege sensitivities down to one to five DNA genomic copies, which can be comparable to the sensitivities stated in ELISA kits (Table 3). As expected, by the high specificity of these kits, no cross-reactivity phenomena are reported for cashew nut.

In addition to the commercial kits, some in-house developed real-time PCR systems have been proposed for the detection of cashew nut in raw and processed foods (Table 5) [129-132]. The spectrum of analysed food samples includes chocolates, biscuits, ice creams, spreads and pesto, amongst others. For quantitative purposes, most of the developed realtime PCR systems targeted single copy genes (Ana o 1, Ana o 2 or Ana o 3) (Table 5), since they are considered the best choices owing to the more constant copy number in different cells from distinct tissues [122]. However, the sensitivities of the systems targeting single copy genes are frequently lower $(\sim 100 \mathrm{mg} / \mathrm{kg}$ of cashew nut in matrix) than those using multicopy genes (e.g. internal transcribed spacer) $(\sim 0.1 \mathrm{mg} / \mathrm{kg}$ of cashew nut in matrix) (Table 5). As for the commercial kits, the reported real-time PCR systems also present high specificity for cashew nut without cross-reactivity with other plant and animal species. Two multiplex real-time PCR have been proposed as multi-target platforms, enabling detecting cashew nut from a wide variety of food matrices with high specificity and sensitivity (Table 5) [133, 134].

\section{$L P A$}

Ligation-dependent probe amplification (LPA) has been proposed for food analysis, particularly for allergen detection. Basically, the method consists on the amplification of PCR products that result from the ligation of bipartite specific hybridisation probes (normally two) and uses a single pair of PCR primers to amplify several target sequences. A fragment of unique size is produced after amplification, being discriminated by capillary electrophoresis. The amplification efficiency is similar for all fragments because they are products from the same set of primers, resulting in a competitive PCR [122].

A LPA was successfully proposed by Ehlert et al. [135] for the simultaneous detection of 10 allergenic foods (peanut, cashew nut, pecan, pistachio, hazelnut, sesame, macadamia nut, almond, walnut and Brazil nut) in different matrices (cookies, pesto and chocolates). The specificity of the probes was evaluated with 56 plant and animal species, thus ensuring the absence of unspecific amplifications as result of crossreactivity. In the case of cashew nut, the multiplex LPA system enabled its detection down to a level of $5 \mathrm{mg} / \mathrm{kg}$ in pesto matrix (Table 5).

\section{Genosensors/Microarrays}

DNA-biosensors (also known as genosensors) have become excellent tools for the detection of sequence-specific DNA fragments, mainly due to their simplicity, low-cost, automation 


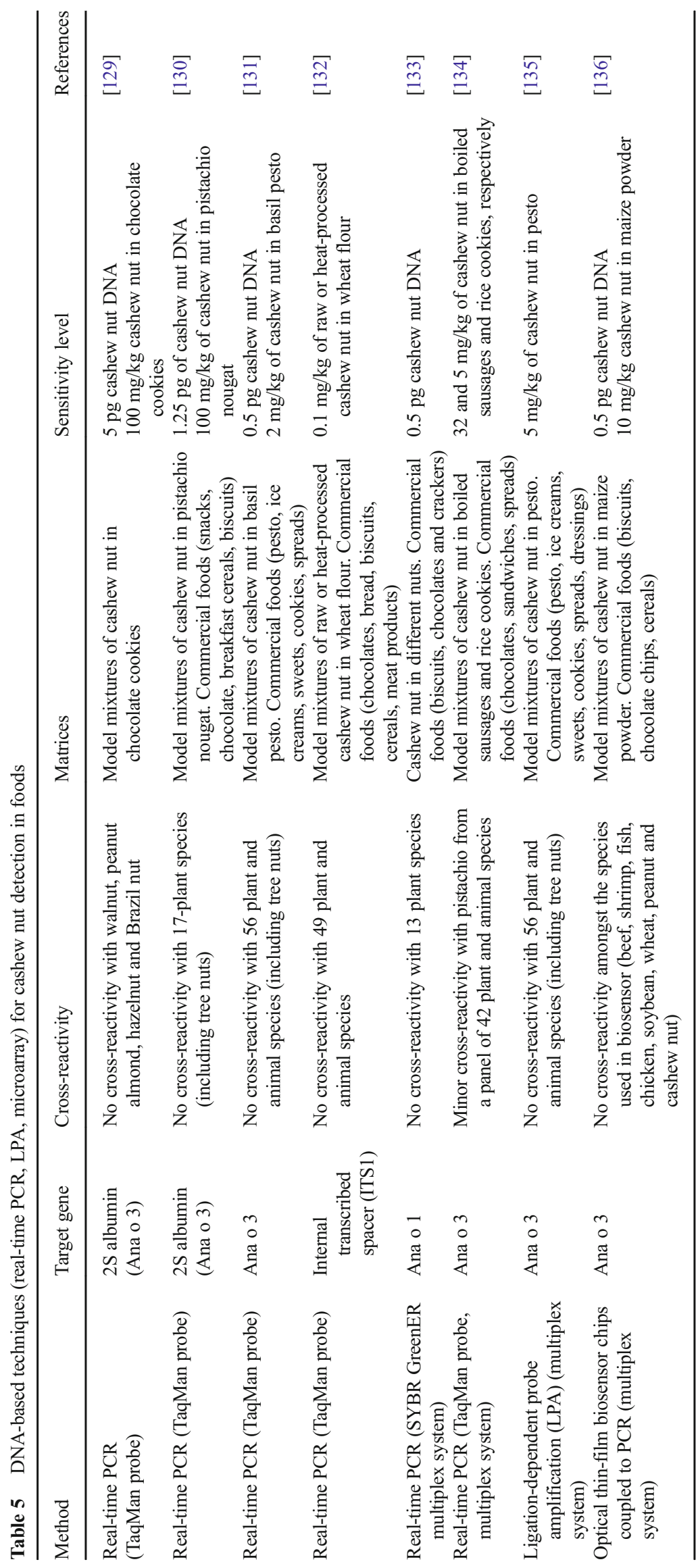


and high selectivity/specificity. Genosensors share the same biosensing technology of immunosensors, although they are based on a different biological interaction. They rely on the hybridisation of two complementary strands: a probe and its complementary sequence (RNA or DNA), as the receptor and target analyte, respectively [122, 123]. Assembling genosensors in microarray platforms allows the simultaneous multiple target detection and thus the development of multiplex approaches.

A system of optical thin-film biosensor chips coupled to previous tetraplex PCR amplification was successfully developed for the simultaneous detection of eight allergenic ingredients (soybean, wheat, peanut, cashew nut, shrimp, fish, beef and chicken) in processed foods [136]. The proposed microarray enabled detecting down to $10 \mathrm{mg} / \mathrm{kg}$ of cashew nut in maize powder and $0.5 \mathrm{pg}$ of genomic DNA (Table 5). No cross-reactivity was found amongst the species tested in microarray, being applied to a wide variety of commercial foods.

\section{Final Remarks}

Over the last years, cashew nut allergy has been regarded with special attention since its prevalence seems to be increasing in the industrialised countries. So far, three groups of seed storage allergenic proteins (Ana o 1-vicilin, Ana o 2-legumin and Ana o 3-2S albumin) have been identified and characterised in cashew nut. All proteins have been classified as major allergens of cashew nut, being included in the WHO/ IUIS official list of allergens. As for other tree nuts, minute amounts of cashew nut proteins $(1 \mathrm{mg})$ can induce an adverse immunological response in allergic individuals.

Allergic reactions to cashew nut are commonly severe and near fatal (anaphylaxis), often demanding epinephrine treatment and hospitalisation, especially in children. The intensity and severity of allergic reactions are most difficult to predict due to the influence of several internal and external factors. Therefore, eliminating the allergenic foods from the diet is still the most efficient means of preventing allergic reactions in sensitised/allergic individuals. Accordingly, when carefully electing the processed foods that are commercially available, the allergic individuals have to rely on proper food labelling. Correct label information represents a critical tool for allergen management. In this sense, the control of labelling compliance is much needed, which has prompted the development of proficient analytical methods for allergen analysis.

Contrarily to other pathologies, there is no cure for food allergies. Although some strategies have been used to induce immune modulation and subsequent desensitisation, dietary eviction and the provision of rescue medication in the event of accidental exposures are the most commonly applied measures. Different forms of immunotherapies have been tested aiming at inducing long-term tolerance to the allergenic food.
Oral immunotherapies to induce tolerance to cashew nut are still very scarce, even though they are foreseen as a potential therapeutics for the treatment of cashew nut allergy.

In spite of the significant number of available reports concerning cashew nut allergy, much research is still required in this field, and new advances are expected in the near future.

Acknowledgments This work was supported by FCT/MEC through national funds and co-financed by FEDER, under the Partnership Agreement PT2020 with grant no. UID/QUI/50006/2013-POCI/01/ 0145/FEDER/007265. Joana Costa is grateful to FCT post-doctoral grant (SFRH/BPD/102404/2014) financed by POPH-QREN (subsidised by FSE and MCTES).

\section{Compliance with Ethical Standards}

Conflict of Interest The authors declare that they have no conflict of interest.

\section{References}

1. GRIN-USDA, Germplasm Resources Information NetworkUnited States Department of Agriculture, Beltsville, MD, USA. http://www.ars-grin.gov/. Accessed 12 Jan 2016.

2. Blazdell P (2000) The mighty cashew. Interdiscip Sci Rev 25:220-226

3. Shahidi F, Tan Z (2008) Bioactive compounds from cashew nut and its coproducts. In Alasalvar C and Shahidi F (eds) Tree nuts: composition, phytochemicals, and health effects: an overview. Taylor \& Francis Group, Boca Raton, chapter 10.

4. Nair KPP (2010) Cashew nut (Anacardium occidentale L.). In Nair KPP (ed) Tree crops of the developing world. Elsevier, Amsterdam, chapter 2.

5. Nussinovitch A (2010) Major plant exudates of the world. In Nussinovitch A (ed) Plant gum exudates of the world: sources, distribution, properties, and applications. Taylor \& Francis Group, Boca Raton, chapter 3.

6. FAOSTAT, Food and Agriculture Organization of the United Nations, Statistics Division, Economic and Social Development Department, Rome, Italy. http://faostat3.fao.org/home/E. Accessed 12 Jan 2016.

7. Ros E (2010) Health benefits of nut consumption. Nutrients 2:652-682. doi:10.3390/nu2070652

8. FDA (2003), Administration Qualified Health Claims, letter of enforcement discretion-nuts and coronary heart disease (Docket No 02P-0505), Ingredients, Packaging \& Labeling, Food and Drug Administration, Washington, DC, USA. http://www.fda.gov/Food/IngredientsPackaging Labeling/LabelingNutrition/ucm072926.htm. Accessed 3 February 2016.

9. CODEX STAN 1 (1985) Amended in 1991, 1999, 2001, 2003, 2005, 2008 and 2010 regarding the general standard for the labelling of pre-packaged foods. FAO/WHO standards. Off Codex Stand. http://www.codexalimentarius.org/standards/list-of-standards/ Accessed 3 Feb 2016.

10. Directive 2003/89/EC of 10 November 2003 amending Directive 2000/13/EC regarding indication of the ingredients present in foodstuffs. Off J Eur Union L308:15-18. 
11. Directive 2007/68/EC of 27 November 2007 amending Annex IIIa to Directive 2000/13/EC regarding certain food ingredients. Off J Eur Union L310:11-14.

12. Regulation (EU) No 1169/2011 of 25 October 2011 on the provision of food information to consumers, amending Regulations (EC) No 1924/2006 and (EC) No 1925/2006 of the European Parliament and of the Council, and repealing Commission Directive 87/250/EEC, Council Directive 90/496/EEC, Commission Directive 1999/10/EC, Directive 2000/13/EC of the European Parliament and of the Council, Commission Directives 2002/67/EC and 2008/5/EC and Commission Regulation (EC) No 608/2004. Off J Eur Union L304:18-63.

13. Gendel SM (2012) Comparison of international food allergen labeling regulations. Regul Toxicol Pharmacol 63:279-285. doi:10.1016/j.yrtph.2012.04.007

14. Taylor SL, Baumert JL (2015) Worldwide food allergy labeling and detection of allergens in processed foods. Chem Immunol Allergy 101:227-234. doi:10.1159/000373910

15. Zuidmeer L, Goldhahn K, Rona RJ et al (2008) The prevalence of plant food allergies: a systematic review. J Allergy Clin Immunol 121:1210-1218. doi:10.1016/j.jaci.2008.02.019

16. McWilliam V, Koplin J, Lodge C, Tang M, Dharmage S, Allen K (2015) The prevalence of tree nut allergy: a systematic review. Curr Allergy Asthma Rep 15:1-13. doi:10.1007/s11882-015-0555-8

17. Sicherer SH, Furlong TJ, Munoz-Furlong A, Burks AW, Sampson HA (2001) A voluntary registry for peanut and tree nut allergy: characteristics of the first 5149 registrants. J Allergy Clin Immunol 108:128-132. doi:10.1016/j.jaci.2014.12.1906

18. Fleischer DM, Conover-Walker MK, Matsui EC, Wood RA (2005) The natural history of tree nut allergy. J Allergy Clin Immunol 116:1087-1093. doi:10.1016/j.jaci.2005.09.002

19. Johnson J, Malinovschi A, Alving K, Lidholm J, Borres MP, Nordvall L (2014) Ten-year review reveals changing trends and severity of allergic reactions to nuts and other foods. Acta Paediatr 103:862-867. doi:10.1111/apa.12687

20. Vetander M, Helander D, Flodström C et al (2012) Anaphylaxis and reactions to foods in children - a population-based case study of emergency department visits. Clin Exp Allergy 42:568-577. doi:10.1111/j.1365-2222.2011.03954.x

21. Le TM, Lindner TM, Pasmans SG et al (2008) Reported food allergy to peanut, tree nuts and fruit: comparison of clinical manifestations, prescription of medication and impact on daily life. Allergy 63:910-916. doi:10.1111/j.1398-9995.2008.01688.x

22. Moneret-Vautrin DA (2008) Épidémiologie de l'allergie alimentaire. Rev Fr Allergol 48:171-178. doi:10.1016/j. allerg.2008.01.018

23. De Silva IL, Mehr SS, Tey D, Tang MLK (2008) Paediatric anaphylaxis: a 5-year retrospective review. Allergy 63:1071-1076. doi:10.1111/j.1398-9995.2008.01719.x

24. Davoren M, Peake J (2005) Cashew nut allergy is associated with a high risk of anaphylaxis. Arch Dis Child 90:1084-1085. doi:10.1136/adc.2005.073817

25. Rancé F, Bidat E, Bourrier T, Sabouraud D (2003) Cashew allergy: observations of 42 children without associated peanut allergy. Allergy 58:1311-1314. doi:10.1046/j.1398-9995.2003.00342.x

26. Sicherer SH, Leung DYM (2015) Advances in allergic skin disease, anaphylaxis, and hypersensitivity reactions to foods, drugs, and insects in 2014. J Allergy Clin Immunol 135:357-367. doi:10.1016/j.jaci.2014.12.1906

27. Boyce JA, Assa'ad A, Burks AW et al (2010) Guidelines for the diagnosis and management of food allergy in the United States: report of the NIAID-sponsored expert panel. J Allergy Clin Immunol 126:S1-S58. doi:10.1016/j.jaci.2010.10.007

28. Valenta R, Hochwallner H, Linhart B, Pahr S (2015) Food allergies: the basics. Gastroenterology 148:1120-1131.e1124. doi: 10.1053/j.gastro.2015.02.006
29. Gómez E, Mayorga C, Gómez F et al (2013) Food allergy: management, diagnosis and treatment strategies. Immunotherapy 5:755-768. doi:10.2217/imt.13.63

30. Lupinek C, Wollmann E, Baar A et al (2014) Advances in allergen-microarray technology for diagnosis and monitoring of allergy: the MeDALL allergen-chip. Methods 66:106-119. doi:10.1016/j.ymeth.2013.10.008

31. Clark AT, Anagnostou K, Ewan PW (2007) Cashew nut causes more severe reactions than peanut: case-matched comparison in 141 children. Allergy 62:913-916. doi:10.1111 /j.1398-9995.2007.01447.x

32. van der Valk JPM, Gerth van Wijk R, Dubois AEJ et al (2016) Multicentre double-blind placebo-controlled food challenge study in children sensitised to cashew nut. PLoS One 11:1-12. doi:10.1371/journal.pone.0151055

33. Maloney JM, Rudengren M, Ahlstedt S, Bock SA, Sampson HA (2008) The use of serum-specific IgE measurements for the diagnosis of peanut, tree nut, and seed allergy. J Allergy Clin Immunol 122:145-151. doi:10.1016/j.jaci.2008.04.014

34. van der Valk JPM, Gerth van Wijk R, Hoorn E, Groenendijk L, Groenendijk IM, de Jong NW (2016) Measurement and interpretation of skin prick test results. Clin Transl Allergy 6:8. doi:10.1186/s13601-016-0092-0

35. Savvatianos S, Konstantinopoulos AP, Borga A et al (2015) Sensitization to cashew nut $2 \mathrm{~S}$ albumin, Ana o 3 , is highly predictive of cashew and pistachio allergy in Greek children. $\mathrm{J}$ Allergy Clin Immunol 136:192-194. doi:10.1016/j. jaci.2015.03.037

36. Muraro A, Roberts G, Worm M et al (2014) Anaphylaxis: guidelines from the European Academy of Allergy and Clinical Immunology. Allergy 69:1026-1045. doi:10.1111/all.12437

37. Chowdhury BA, Meyer RJ (2002) Intramuscular versus subcutaneous injection of epinephrine in the treatment of anaphylaxis. J Allergy Clin Immunol 109:720. doi:10.1067/mai.2002.123252

38. Bégin P, Chinthrajah RS, Nadeau KC (2014) Oral immunotherapy for the treatment of food allergy. Hum Vaccines Immunother 10:2295-2302. doi:10.4161/hv.29233

39. Mousallem T, Burks AW (2012) Immunology in the clinic review series; focus on allergies: immunotherapy for food allergy. Clin Exp Immunol 167:26-31. doi:10.1111/j.1365-2249.2011.04499.x

40. Sato S, Yanagida N, Ogura K et al (2014) Clinical studies in oral allergen-specific immunotherapy: differences among allergens. Int Arch Allergy Immunol 164:1-9. doi:10.1159/000361025

41. Sindher S, Fleischer DM, Spergel JM (2016) Advances in the treatment of food allergy: sublingual and epicutaneous immunotherapy. Immunol Allergy Clin North Am 36:39-54. doi:10.1016 /j.iac.2015.08.008

42. Kulis M, Li Y, Lane H, Pons L, Burks W (2011) Single-tree nut immunotherapy attenuates allergic reactions in mice with hypersensitivity to multiple tree nuts. J Allergy Clin Immunol 127:81-88. doi:10.1016/j.jaci.2010.09.014

43. Kulis M, MacQueen I, Li YF, Guo RS, Zhong XP, Burks AW (2012) Pepsinized cashew proteins are hypoallergenic and immunogenic and provide effective immunotherapy in mice with cashew allergy. J Allergy Clin Immunol 130:716-723. doi:10.1016/j.jaci.2012.05.044

44. Okada Y, Yanagida N, Sato S et al (2015) Oral immunotherapy initiation for multi-nut allergy: a case report. Allergol Int 64:192-193. doi:10.1016/j.alit.2014.09.004

45. Bégin P, Dominguez T, Wilson SP et al (2014) Phase 1 results of safety and tolerability in a rush oral immunotherapy protocol to multiple foods using omalizumab. Allergy Asthma Clin Immunol 10:1-10. doi:10.1186/1710-1492-10-7

46. El-Qutob D (2015) Off-label uses of omalizumab. Clin Rev Allergy Immunol 50:84-96. doi:10.1007/s12016-015-8490-y 
47. Entink RHK, Remington BC, Blom WM et al (2014) Food allergy population thresholds: an evaluation of the number of oral food challenges and dosing schemes on the accuracy of threshold dose distribution modeling. Food Chem Toxicol 70:134-143. doi:10.1016/j.fct.2014.05.001

48. Crevel RWR, Baumert JL, Baka A et al (2014) Development and evolution of risk assessment for food allergens. Food Chem Toxicol 67:262-276. doi:10.1016/j.fct.2014.01.032

49. Taylor SL, Baumert JL, Kruizinga AG et al (2014) Establishment of reference doses for residues of allergenic foods: report of the VITAL expert panel. Food Chem Toxicol 63:9-17. doi:10.1016/j. fct.2013.10.032

50. Blom WM, Vlieg-Boerstra BJ, Kruizinga AG, van der Heide S, Houben GF, Dubois AEJ (2013) Threshold dose distributions for 5 major allergenic foods in children. J Allergy Clin Immunol 131:172-179. doi:10.1016/j.jaci.2012.10.034

51. Allen KJ, Remington BC, Baumert JL et al (2014) Allergen reference doses for precautionary labeling (VITAL 2.0): clinical implications. J Allergy Clin Immunol 133:156-164. doi:10.1016/j. jaci.2013.06.042

52. Radauer C, Bublin M, Wagner S, Mari A, Breiteneder H (2008) Allergens are distributed into few protein families and possess a restricted number of biochemical functions. J Allergy Clin Immunol 121:847-852.e847. doi: 10.1016/j.jaci.2008.01.025

53. Jenkins JA, Griffiths-Jones S, Shewry PR, Breiteneder H, Mills ENC (2005) Structural relatedness of plant food allergens with specific reference to cross-reactive allergens: an in silico analysis. J Allergy Clin Immunol 115:163-170. doi:10.1016/j. jaci.2004.10.026

54. Harrer A, Egger M, Gadermaier G et al (2010) Characterization of plant food allergens: an overview on physicochemical and immunological techniques. Mol Nutr Food Res 54:93-112. doi:10.1002 /mnfr.200900096

55. Moreno FJ (2007) Gastrointestinal digestion of food allergens: effect on their allergenicity. Biomed Pharmacother 61:50-60. doi:10.1016/j.biopha.2006.10.005

56. Moreno FJ, Clemente A (2008) $2 \mathrm{~S}$ albumin storage proteins: what makes them food allergens? Open Biochem J 2:16-28. doi:10.2174/1874091X00802010016

57. van der Valk JPM, Dubois AEJ, Gerth van Wijk R, Wichers HJ, de Jong NW (2014) Systematic review on cashew nut allergy. Allergy 69:692-698. doi:10.1111/all.12401

58. Grigg A, Hanson C, Davis CM (2009) Cashew allergy compared to peanut allergy in a US tertiary care center. Pediatr Asthma Allergy Immunol 22:101-104. doi:10.1089/pai.2009.0017

59. ALLERGEN, World Health Organization and International Union of Immunological Societies (WHO/IUIS) Allergen Nomenclature Sub-committee official site for the systematic allergen nomenclature. http://www.allergen.org/. Accessed 18 Feb 2016.

60. Radauer C, Breiteneder H (2007) Evolutionary biology of plant food allergens. J Allergy Clin Immunol 120:518-525. doi:10.1016/j.jaci.2007.07.024

61. Breiteneder H, Mills ENC (2005) Plant food allergens - structural and functional aspects of allergenicity. Biotechnol Adv 23:395-399. doi:10.1016/j.biotechadv.2005.05.004

62. Breiteneder H, Radauer C (2004) A classification of plant food allergens. J Allergy Clin Immunol 113:821-830. doi:10.1016/j. jaci.2004.01.779

63. ALLERGOME, allergome database, the platform for allergen knowledge, Latina, Italy. http://www.allergome.org/. Accessed $18 \mathrm{Feb} 2016$.

64. Chapman MD, Pomés A, Breiteneder H, Ferreira F (2007) Nomenclature and structural biology of allergens. J Allergy Clin Immunol 119:414 420. doi:10.1016/j.jaci.2006.11.001

65. Wang F, Robotham JM, Teuber SS, Tawde P, Sathe SK, Roux KH (2002) Ana o 1, a cashew (Anacardium occidental) allergen of the vicilin seed storage protein family. J Allergy Clin Immunol 110:160-166. doi:10.1067/mai.2002.125208

66. Guan XY, Noble KA, Tao YQ et al (2015) Epitope mapping of 7S cashew antigen in complex with antibody by solution-phase H/D exchange monitored by FT-ICR mass spectrometry. J Mass Spectrom 50:812-819. doi:10.1002/jms.3589

67. Reitsma M, Bastiaan-Net S, Sforza S et al (2016) Purification and characterization of Anacardium occidentale (cashew) allergens Ana o 1, Ana o 2, and Ana o 3. J Agric Food Chem 64:1191-1201. doi:10.1021/acs.jafc.5b04401

68. Barre A, Sordet C, Culerrier R, Rance F, Didier A, Rouge P (2008) Vicilin allergens of peanut and tree nuts (walnut, hazelnut and cashew nut) share structurally related IgE-binding epitopes. Mol Immunol 45:1231-1240. doi:10.1016/j.molimm.2007.09.014

69. Kulis M, Pons L, Burks AW (2009) In vivo and T cell crossreactivity between walnut, cashew and peanut. Int Arch Allergy Immunol 148:109-117. doi:10.1159/000155741

70. de Leon MP, Glaspole IN, Drew AC, Rolland JM, O'Hehir RE, Suphioglu C (2003) Immunological analysis of allergenic crossreactivity between peanut and tree nuts. Clin Exp Allergy 33:1273-1280. doi:10.1046/j.1365-2222.2003.01761.x

71. Fernandez C, Fiandor A, Martinez-Garate A, Quesada JM (1995) Allergy to pistachio: cross-reactivity between pistachio nut and other Anacardiaceae. Clin Exp Allergy 25:1254-1259. doi:10.1111/j.1365-2222.1995.tb03050.x

72. Garcia F, Moneo I, Fernandez B et al (2000) Allergy to Anacardiaceae: description of cashew and pistachio nut allergens. J Invest Allergol Clin Immunol 10:173-177

73. Hasegawa M, Inomata N, Yamazaki H, Morita A, Kirino M, Ikezawa Z (2009) Clinical features of four cases with cashew nut allergy and cross-reactivity between cashew nut and pistachio. Allergol Int 58:209-215. doi:10.2332/allergolint.08-OA-0010

74. Rougé P, Thibau F, Bourrier T, Saggio B, Culerrier R, Rancé F, Barre A (2011) Clinical relevance of IgE-binding cross-reactivity of allergens from cashew nut (Anacardium occidentale). Rev Fr Allergol 51:31-35. doi:10.1016/j.reval.2010.10.005

75. Willison LN, Tawde P, Robotham JM et al (2008) Pistachio vicilin, Pis $\vee 3$, is immunoglobulin E-reactive and cross-reacts with the homologous cashew allergen, Ana o 1. Clin Exp Allergy 38:1229-1238. doi:10.1111/j.1365-2222.2008.02998.x

76. Mills EN, Jenkins J, Marigheto N, Belton PS, Gunning AP, Morris VJ (2002) Allergens of the cupin superfamily. Biochem Soc Trans 30:925-929. doi:10.1042/bst0300925

77. Teuber SS, Sathe SK, Peterson WR, Roux KH (2002) Characterization of the soluble allergenic proteins of cashew nut (Anacardium occidentale L.). J Agric Food Chem 50:6543-6549. doi:10.1021/jf025757j

78. Wang F, Robotham JM, Teuber SS, Sathe SK, Roux KH (2003) Ana o 2, a major cashew (Anacardium occidentale L.) nut allergen of the legumin family. Int Arch Allergy Immunol 132:27-39. doi:10.1159/000073262

79. Robotham JM, Hoffman GG, Teuber SS et al (2009) Linear IgE-epitope mapping and comparative structural homology modeling of hazelnut and English walnut 11S globulins. Mol Immunol 46:2975-2984. doi:10.1016/j.molimm.2009.06.020

80. Barre A, Jacquet G, Sordet C, Culerrier R, Rougé P (2007) Homology modelling and conformational analysis of IgEbinding epitopes of Ara h 3 and other legumin allergens with a cupin fold from tree nuts. Mol Immunol 44:3243-3255. doi:10.1016/j.molimm.2007.01.023

81. Robotham JM, Xia LX, Willison LN, Teuber SS, Sathe SK, Roux $\mathrm{KH}$ (2010) Characterization of a cashew allergen, 11S globulin (Ana o 2), conformational epitope. Mol Immunol 47:1830-1838. doi:10.1016/j.molimm.2009.12.009

82. Xia LX, Willison LN, Porter L et al (2010) Mapping of a conformational epitope on the cashew allergen Ana o 2: a discontinuous 
large subunit epitope dependent upon homologous or heterologous small subunit association. Mol Immunol 47:1808-1816. doi:10.1016/j.molimm.2010.01.018

83. Kshirsagar HH, Fajer P, Sharma GM, Roux KH, Sathe SK (2011) Biochemical and spectroscopic characterization of almond and cashew nut seed 11S legumins, amandin and anacardein. J Agric Food Chem 59:386-393. doi:10.1021/jf1030899

84. Chung SY, Mattison CP, Reed S, Wasserman RL, Desormeaux WA (2015) Treatment with oleic acid reduces IgE binding to peanut and cashew allergens. Food Chem 180:295-300. doi:10.1016 /j.foodchem.2015.02.056

85. Shewry PR, Halford NG (2002) Cereal seed storage proteins: structures, properties and role in grain utilization. J Exp Bot 53:947-958. doi:10.1093/jexbot/53.370.947

86. Breiteneder H, Ebner C (2000) Molecular and biochemical classification of plant-derived food allergens. J Allergy Clin Immunol 106:27-36. doi:10.1067/mai.2000.106929

87. Pantoja-Uceda D, Bruix M, Santoro J, Rico M, Monsalve R, Villaba M (2002) Solution structure of allergenic $2 \mathrm{~S}$ albumins. Biochem Soc Trans 30:919-924. doi:10.1042/bst0300919

88. Shewry PR, Napier JA, Tatham AS (1995) Seed storage proteins-structures and biosynthesis. Plant Cell 7:945-956. doi:10.1105/tpc.7.7.945

89. Terras FRG, Torrekens S, Van Leuven F et al (1993) A new family of basic cysteine-rich plant antifungal proteins from Brassicaceae species. FEBS Lett 316:233-240. doi:10.1016/0014-5793(93)81299-F

90. Polya GM, Chandra S, Condron R (1993) Purification and sequencing of radish seed calmodulin antagonists phosphorylated by calcium-dependent protein kinase. Plant Physiol 101:545-551. doi:10.1104/pp.101.2.545

91. Sampson HA, Aceves S, Bock SA et al. (2014) Food allergy: a practice parameter update-2014. J Allergy Clin Immunol 134: 1016-1025.e43. doi: 10.1016/j.jaci.2014.05.013

92. Robotham JM, Wang F, Seamon V et al (2005) Ana o 3, an important cashew nut (Anacardium occidentale $\mathrm{L}$.) allergen of the $2 \mathrm{~S}$ albumin family. J Allergy Clin Immunol 115:1284-1290. doi:10.1016/j.jaci.2005.02.028

93. Ahn K, Bardina L, Grishina G, Beyer K, Sampson HA (2009) Identification of two pistachio allergens, Pis $\mathrm{v} 1$ and Pis v 2, belonging to the $2 \mathrm{~S}$ albumin and $11 \mathrm{~S}$ globulin family. Clin Exp Allergy 39:926-934. doi:10.1111/j.1365-2222.2009.03259.x

94. Moreno FJ, Jenkins JA, Mellon FA et al (2004) Mass spectrometry and structural characterization of $2 \mathrm{~S}$ albumin isoforms from Brazil nuts (Bertholletia excelsa). Biochim Biophys Acta 1698:175-186. doi:10.1016/j.bbapap.2003.11.007

95. Moreno FJ, Maldonado BM, Wellner N, Mills ENC (2005) Thermostability and in vitro digestibility of a purified major allergen 2S albumin (Ses i 1) from white sesame seeds (Sesamum indicum L.). Biochim Biophys Acta 1752:142-153. doi:10.1016/j.bbapap.2005.07.022

96. Vanga SK, Singh A, Raghavan V (in press) Review of conventional and novel food processing methods on food allergens. Crit Rev Food Sci Nutr. doi: 10.1080/10408398.2015.1045965.

97. Mills ENC, Mackie AR (2008) The impact of processing on allergenicity of food. Curr Opin Allergy Clin Immunol 8:249 253. doi:10.1097/ACI.0b013e3282ffb 123

98. Mills ENC, Sancho AI, Rigby NM, Jenkins JA, Mackie AR (2009) Impact of food processing on the structural and allergenic properties of food allergens. Mol Nutr Food Res 53:963-969. doi:10.1002/mnfr.200800236

99. Su M, Venkatachalam M, Teuber SS, Roux KH, Sathe SK (2004) Impact of gamma-irradiation and thermal processing on the antigenicity of almond, cashew nut and walnut proteins. J Sci Food Agric 84:1119-1125. doi:10.1002/jsfa. 1748
100. Venkatachalam M, Monaghan EK, Kshirsagar HH et al (2008) Effects of processing on immunoreactivity of cashew nut (Anacardium occidentale L.) seed flour proteins. J Agric Food Chem 56:8998-9005. doi:10.1021/jf801199q

101. Mattison CP, Desormeaux WA, Wasserman RL, Yoshioka-Tarver M, Condon B, Grimm CC (2014) Decreased immunoglobulin E (IgE) binding to cashew allergens following sodium sulfite treatment and heating. J Agric Food Chem 62:6746-6755. doi:10.1021 jj501117p

102. Untersmayr E, Jensen-Jarolim E (2008) The role of protein digestibility and antacids on food allergy outcomes. J Allergy Clin Immunol 121:1301-1308. doi:10.1016/j.jaci.2008.04.025

103. Mattison CP, Grimm CC, Wasserman RL (2014) In vitro digestion of soluble cashew proteins and characterization of surviving IgE-reactive peptides. Mol Nutr Food Res 58:884-893. doi:10.1002/mnfr.201300299

104. Crevel RWR, Baumert JL, Luccioli S (2014) Translating reference doses into allergen management practice: challenges for stakeholders. Food Chem Toxicol 67:277-287. doi:10.1016/j. fct.2014.01.033

105. Crevel RWR, Ballmer-Weber BK, Holzhauser T (2008) Thresholds for food allergens and their value to different stakeholders. Allergy 63:597-609. doi:10.1111/j.1398-9995.2008.01636.x

106. Luccioli S (2012) Food allergy guidelines and assessing allergic reaction risks: a regulatory perspective. Curr Opin Allergy Clin Immunol 12:323-330. doi:

107. Costa J, Carrapatoso I, Oliveira MBPP, Mafra I (2014) Walnut allergens: molecular characterization, detection and clinical relevance. Clin Exp Allergy 44:319-341. doi:10.1111/cea.12267

108. Costa J, Mafra I, Carrapatoso I, Oliveira M (in press) Hazelnut allergens: molecular characterisation, detection and clinical relevance. Crit Rev Food Sci Nutr. doi: 10.1080/10408398.2013.826173.

109. Johnson PE, Sancho AI, Crevel RWR, Mills ENC (2011) Detection of allergens in foods. In: Nollet LML, van Hengel AJ (eds) Food allergens: analysis instrumentation and methods. CRC Press, Taylor \& Francis Group, Boca Raton, pp 13-27

110. Schubert-Ullrich P, Rudolf J, Ansari et al (2009) Commercialized rapid immunoanalytical tests for determination of allergenic food proteins: an overview. Anal Bioanal Chem 395:69-81. doi:10.1007/s00216-009-2715-y

111. Wei Y, Sathe SK, Teuber SS, Roux KH (2002) A sensitive sandwich ELISA for the detection of trace amount of cashew nut in foods. J Allergy Clin Immunol 109(1 supp 1):S303. doi:10.1016 /S0091-6749(02)82063-2

112. Wei YH, Sathe SK, Teuber SS, Roux KH (2003) A sensitive sandwich ELISA for the detection of trace amounts of cashew (Anacardium occidentale L.) nut in foods. J Agric Food Chem 51:3215-3221. doi:10.1021/jf025977x

113. Gaskin FE, Niemann LM, Hefle SL, Taylor SL (2009) Validated enzyme-linked immunosorbent assay (ELISA) for detection of undeclared cashew nut residues in foods. J Allergy Clin Immunol 123(2, Supplement):S245. doi:10.1016/j. jaci.2008.12.946

114. Gaskin FE, Taylor SL (2011) Sandwich enzyme-linked immunosorbent assay (ELISA) for detection of cashew nut in foods. J Food Sci 76:T218-T226. doi:10.1111/j.1750-3841.2011.02407.x

115. Rejeb SB, Abbott M, Davies D, Cleroux C, Delahaut P (2005) Multi-allergen screening immunoassay for the detection of protein markers of peanut and four tree nuts in chocolate. Food Addit Contam 22:709-715. doi:10.1080/026520030500158450

116. Cho CY, Nowatzke W, Oliver K, Garber EAE (2015) Multiplex detection of food allergens and gluten. Anal Bioanal Chem 407:4195-4206. doi:10.1007/s00216-015-8645-y

117. Rebe Raz S, Liu H, Norde W, Bremer MGEG (2010) Food allergens profiling with an imaging surface plasmon resonance-based biosensor. Anal Chem 82:8485-8491. doi:10.1021/ac101819g 
118. Bignardi C, Elviri L, Penna A, Careri M, Mangia A (2010) Particlepacked column versus silica-based monolithic column for liquid chromatography-electrospray-linear ion trap-tandem mass spectrometry multiallergen trace analysis in foods. J Chromatogr A 1217:7579-7585. doi:10.1016/j.chroma.2010.10.037

119. Bignardi C, Mattarozzi M, Penna A et al (2013) A rapid sizeexclusion solid-phase extraction step for enhanced sensitivity in multi-allergen determination in dark chocolate and biscuits by liquid chromatography-tandem mass spectrometry. Food Anal Meth 6:1144-1152. doi:10.1007/s12161-012-9521-4

120. Sealey-Voyksner J, Zweigenbaum J, Voyksner R (2016) Discovery of highly conserved unique peanut and tree nut peptides by LC-MS/MS for multi-allergen detection. Food Chem 194:201-211. doi:10.1016/j.foodchem.2015.07.043

121. Pilolli R, Monaci L, Visconti A (2013) Advances in biosensor development based on integrating nanotechnology and applied to food-allergen management. Trac-Trends Anal Chem 47:12-26. doi:10.1016/j.trac.2013.02.005

122. Prado M, Ortea I, Vial S, Rivas J, Calo-Mata P, Barros-Velázquez J (in press) Advanced DNA- and protein-based methods for the detection and investigation of food allergens. Crit Rev Food Sci Nutr. doi:10.1080/10408398.2013.873767

123. Alves RC, Barroso MF, González-García MB, Oliveira MBPP, Delerue-Matos MC (in press) New trends in food allergens detection: towards biosensing strategies. Crit Rev Food Sci Nutr. doi:10.1080/10408398.2013.831026

124. Cunsolo V, Muccilli V, Saletti R, Foti S (2014) Mass spectrometry in food proteomics: a tutorial. J Mass Spectrom 49:768-784. doi:10.1002/jms.3374

125. Fæste CK, Rønning HT, Christians U, Granum PE (2011) Liquid chromatography and mass spectrometry in food allergen detection. J Food Prot 74:316-345. doi:10.4315/0362-028X.JFP-10-336

126. Monaci L, Visconti A (2009) Mass spectrometry-based proteomics methods for analysis of food allergens. Trac-Trend Anal Chem 28:581-591. doi:10.1016/j.trac.2009.02.013
127. Picariello G, Mamone G, Addeo F, Ferranti P (2011) The frontiers of mass spectrometry-based techniques in food allergenomics. $\mathrm{J}$ Chromatogr A 1218:7386-7398. doi:10.1016/j.chroma.2011.06.033

128. Costa J, Mafra I, Carrapatoso I, Oliveira M (2012) Almond allergens: molecular characterization, detection, and clinical relevance. J Agric Food Chem 60:1337-1349. doi:10.1021/jf2044923

129. Brzezinski JL (2006) Detection of cashew nut DNA in spiked baked goods using a real-time polymerase chain reaction method. J AOAC Int 89:1035-1038

130. Piknova L, Kuchta T (2007) Detection of cashew nuts in food by real-time polymerase chain reaction. J Food Nutr Res 46:101-104

131. Ehlert A, Hupfer C, Demmel A, Engel KH, Busch U (2008) Detection of cashew nut in foods by a specific real-time PCR method. Food Anal Meth 1:136-143. doi:10.1007/s12161-008-9023-6

132. Lopez-Calleja IM, de la Cruz S, Gonzalez I, Garcia T, Martin R (2015) Development of real-time PCR assays to detect cashew (Anacardium occidentale) and macadamia (Macadamia intergrifolia) residues in market analysis of processed food products. LWT-Food Sci Technol 62:233-241. doi:10.1016/j. lwt.2015.01.023

133. Pafundo S, Gulli M, Marmiroli N (2010) Multiplex real-time PCR using SYBR GreenER for the detection of DNA allergens in food. Anal Bioanal Chem 396:1831-1839. doi:10.1007/s00216-009-3419-Z

134. Koppel R, van Velsen-Zimmerli F, Bucher T (2012) Two quantitative hexaplex real-time PCR systems for the detection and quantification of DNA from twelve allergens in food. Eur Food Res Technol 235:843-852. doi:10.1007/s00217-012-1806-8

135. Ehlert A, Demmel A, Hupfer C, Busch U, Engel KH (2009) Simultaneous detection of DNA from 10 food allergens by ligation-dependent probe amplification. Food Addit Contam A 26:409-418. doi:10.1080/02652030802593529

136. Wang W, Han JX, Wu YJ, Yuan F, Chen Y, Ge YQ (2011) Simultaneous detection of eight food allergens using optical thin-film biosensor chips. J Agric Food Chem 59:6889-6894. doi:10.1021/jf200933b 